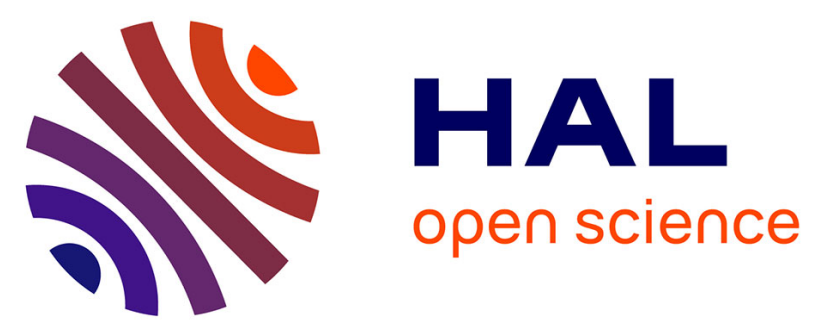

\title{
Comparative shotgun proteomic analysis of wild and domesticated Opuntia spp. species shows a metabolic adaptation through domestication
}

\author{
Carole Pichereaux, Eric E. Hernandez-Dominguez, Maria del Socorro \\ Santos-Diaz, Antonio Reyes-Aguero, Marizel Astello-Garcia, Françoise \\ Guéraud, Anne Negre-Salvayre, Odile Schiltz, Michel Rossignol, Ana Paulina \\ Barba de La Rosa
}

\section{- To cite this version:}

Carole Pichereaux, Eric E. Hernandez-Dominguez, Maria del Socorro Santos-Diaz, Antonio ReyesAguero, Marizel Astello-Garcia, et al.. Comparative shotgun proteomic analysis of wild and domesticated Opuntia spp. species shows a metabolic adaptation through domestication. Journal of Proteomics, 2016, 143 (6), pp.353-364. 10.1016/j.jprot.2016.04.003 . hal-01602455

\section{HAL Id: hal-01602455 \\ https://hal.science/hal-01602455}

Submitted on 19 Mar 2021

HAL is a multi-disciplinary open access archive for the deposit and dissemination of scientific research documents, whether they are published or not. The documents may come from teaching and research institutions in France or abroad, or from public or private research centers.
L'archive ouverte pluridisciplinaire HAL, est destinée au dépôt et à la diffusion de documents scientifiques de niveau recherche, publiés ou non, émanant des établissements d'enseignement et de recherche français ou étrangers, des laboratoires publics ou privés. 


\section{Accepted Manuscript}

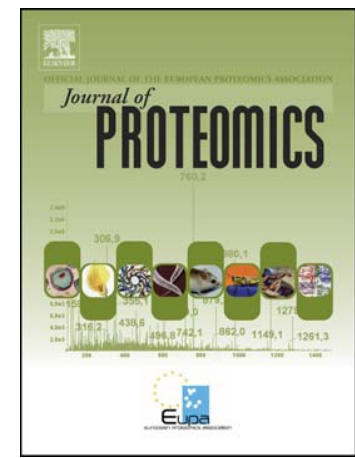

Comparative shotgun proteomic analysis of wild and domesticated Opuntia spp. species shows a metabolic adaptation through domestication

Carole Pichereaux, Eric E. Hernández-Domínguez, Maria del Socorro Santos Diaz, Antonio Reyes-Agüero, Marizel Astello-García, Françoise Guéraud, Anne Negre-Salvayre, Odile Schiltz, Michel Rossignol, Ana Paulina Barba de la Rosa

PII:

DOI:

Reference:

To appear in:

Received date:

Revised date:

Accepted date:
S1874-3919(16)30117-8

doi: 10.1016/j.jprot.2016.04.003

JPROT 2492

\section{Journal of Proteomics}

18 December 2015

1 April 2016

4 April 2016

Please cite this article as: Pichereaux Carole, Hernández-Domínguez Eric E., del Socorro Santos Diaz Maria, Reyes-Agüero Antonio, Astello-García Marizel, Guéraud Françoise, Negre-Salvayre Anne, Schiltz Odile, Rossignol Michel, de la Rosa Ana Paulina Barba, Comparative shotgun proteomic analysis of wild and domesticated Opuntia spp. species shows a metabolic adaptation through domestication, Journal of Proteomics (2016), doi: 10.1016/j.jprot.2016.04.003

This is a PDF file of an unedited manuscript that has been accepted for publication. As a service to our customers we are providing this early version of the manuscript. The manuscript will undergo copyediting, typesetting, and review of the resulting proof before it is published in its final form. Please note that during the production process errors may be discovered which could affect the content, and all legal disclaimers that apply to the journal pertain. 


\section{Comparative shotgun proteomic analysis of wild and domesticated Opuntia spp. species shows a metabolic adaptation through domestication}

Carole Pichereaux ${ }^{1,2}$, Eric E. Hernández-Domínguez ${ }^{3, \dagger}$, Maria del Socorro Santos Diaz $^{4}$, Antonio Reyes-Agüero ${ }^{5}$, Marizel Astello-García ${ }^{3}$, Françoise Guéraud ${ }^{6}$, Anne Negre-Salvayre ${ }^{7}$, Odile Schiltz ${ }^{2}$, Michel Rossignol ${ }^{1,2^{*}}$, Ana Paulina Barba de la Rosa $^{3, *}$

${ }^{1}$ Institut de Pharmacologie et de Biologie Structurale-Fédération de Recherche Agrobiosciences, Interactions et Biodiversité, CNRS, Université de Toulouse, 205 route de Narbonne, 31077 Toulouse

${ }^{2}$ Institut de Pharmacologie et de Biologie Structurale-CNRS, Université de Toulouse, 205 route de Narbonne, 31077 Toulouse

${ }^{3}$ IPICyT, Instituto Potosino de Investigación Científica y Tecnológica A.C., San Luis Potosi, Mexico

${ }^{4}$ Facultad de Ciencias Químicas de la Universidad Autónoma de San Luis Potosi, Mexico

${ }^{5}$ Instituto de Investigación en Zonas Desérticas, Universidad Autónoma de San Luis Potosi, Mexico

${ }^{6}$ INRA UMR1331, TOXALIM, Toulouse, France

${ }^{7}$ INSERM UMR 1048, Toulouse, France

†Current address: CONACyT Research Fellow-Instituto de Ecología A.C. (INECOL), Red de Estudios Moleculares Avanzados (REMAV), Xalapa, Veracruz, México.

\section{Correspondence}

Dr. Ana Paulina Barba

Instituto Potosino de Investigación Científica y Tecnológica A.C.

Molecular Biology Department

Camino a la Presa San José No. 2055,

Lomas 4a Sección

San Luis Potosi, S.L.P., 78216 Mexico

apbarba@ipicyt.edu.mx

Dr. Michel Rossignol

Institut de Pharmacologie et de Biologie Structurale-Fédération de Recherche Agrobiosciences, Interactions et Biodiversité, CNRS, Université de Toulouse,

205 route de Narbonne, 31077 Toulouse

carole.pichereaux@ipbs.fr 


\section{Abstract}

The Opuntia genus is widely distributed in America, but the highest richness of wild species are found in Mexico, as well as the most domesticated $O$. ficus-indica, which is the most domesticated species and an important crop in agricultural economies of arid and semiarid areas worldwide. During domestication process, the Opuntia morphological characteristics were favoured, such as less and smaller spines in cladodes and less seeds in fruits, but changes at molecular level are almost unknown. To obtain more insights about the Opuntia molecular changes through domestication, a shotgun proteomic analysis and database-dependent searches by homology was carried out. More than 1000 protein species were identified and by using a label-free quantitation method, the Opuntia proteomes were compared in order to identify differentially accumulated proteins among wild and domesticated species. Most of the changes were observed in glucose, secondary, and $1 \mathrm{C}$ metabolism, which correlate with the observed protein, fiber and phenolic compounds accumulation in Opuntia cladodes. Regulatory proteins, ribosomal proteins, and proteins related with response to stress were also observed in differential accumulation. These results provide new valuable data that will help to the understanding of the molecular changes of Opuntia species through domestication.

\section{Biological Significance}

Opuntia species are well adapted to dry and warm conditions in arid and semiarid regions worldwide, they are highly productive plants showing considerable promises as an alternative food source. However, there is a gap regarding Opuntia molecular mechanisms that enable them to grow in extreme environmental conditions and how the domestication processes has changed them. In the 
present study, a shotgun analysis was carried out to characterize the proteomes of five Opuntia species selected by its domestication degree. Our results will help to a better understanding of proteomic features underlying the selection and specialization under evolution and domestication of Opuntia and will provide a platform for basic biology research and gene discovery.

Keywords: Carbohydrate metabolism; domestication; 1C-metabolism; Opuntia spp.; LC-MS/MS; shotgun analysis

\section{This article is part of a Special Issue entitled: Food Crop Proteomics}

\section{Introduction}

Domestication is an evolutionary process in which human selection or humanization is the crucial force causing genetic changes to favor the survival and reproduction of particular phenotypes of plant or animal species [1]. The resulting domesticated populations generally diverge from their parental wild populations in morphological, physiological and behavioral features [2-4]. Plant domestication is accompanied by shifts in resource allocation, as a result of farmer selection for genotypes that give higher yields in agricultural habitats. Plants favored are generally those with higher use, cultural and/or economic value and may involve artificial selection directed to increase abundance of favorable phenotypes [5].

Cacti are native of the New World, and their main distribution areas are arid and semiarid zones [6]. In Mexico, since prehistory, ancient indigenous peoples used cacti as food, medicines, tools, and for religious and magical practices [7]. 
Among the Cactaceae family, Opuntia is one of the most diverse and widely distributed genus in America; it includes 188 species, 78 of them being native of Mexico [8], where highest richness of wild variants and cultivars of the world can be found, and at least 126 with different degrees of domestication [9].

There are evidences that during the process of Opuntia domestication, the continuous and systematic gather of nopalitos (edible young cladodes) and fruit favored the development of exceptional features with the purpose to adapt plants to successfully live in human-made environment to maximize yield or any given selected feature [3]. The Opuntia fruit has been enhanced on flavor, size, shape, pulp texture, and decreased of seed hardness and seed quantity. In regard to nopalitos, changes occurred in shape, color, earliness, flavor, texture, and quantity and quality of mucilages [9].

A gradient of domestication can be appreciated in species of the Opuntia genus, wild species like $O$. streptacantha and $O$. hyptiacantha, others semi domesticated like O. megacantha, and O. albicarpa [9], and at the end of the gradient $O$. ficus-indica, which is a long-domesticated cactus crop that is important in agricultural economies throughout arid and semiarid parts of the world. Comparative studies of domesticated plants and their ancestors are a promising avenue to explore the molecular changes through evolution and to design strategies to improve plant breeding [10]. Since mass spectrometry (MS)-based proteomics requires the availability of a protein database, proteomic studies in plant systems have primarily been performed in fully sequenced model systems such as Arabidopsis thaliana, Oryza sativa, but also have been reported in plants with incomplete sequence information such as Catharanthus roseus [11], Panax ginseng [12], and Amaranthus cruentus [13]. Recently proteomics has been used 
as a powerful tool to investigate the molecular changes of cotton fiber through domestication $[14,15]$. Proteomics is also a promise tool to obtain information about signatures of wild and domesticated plants, characteristics that have the potential to direct the crop improvement strategies directed to select traits of agronomic and nutritional importance [16].

The typical plant proteomic experiments utilize two-dimensional gel electrophoresis (2-DE) followed by protein identification by mass spectrometry. Although very powerful and offering a number of advantages, 2-DE yields relatively low number of identified proteins due to inherent limitations of this approach. For that, shotgun proteomic has been applied to increase the coverage of the proteome of plants such as wheat [17] and Medicago truncatula [18].

In this work, a comparative shotgun proteomic analysis of five Opuntia species with different domestication grade was carried out. More than 1000 protein species were detected in the Opuntia species and the differentially protein accumulation among wild and domesticated species was analyzed. Those proteins corresponded to metabolic pathways such glucose, secondary, and 1Cmetabolism, which correlate with the observed protein, fiber and phenolic compounds accumulation in Opuntia cladodes among species. Interestingly a wellrepresented group of regulatory protein species such as proteasome and 14-3-3 were identified in all Opuntia samples. The present data shows the Opuntia molecular changes through domestication and will help to understand the agronomic and nutraceutical characteristics of wild and domesticated Opuntia species.

\section{Materials and Methods}




\subsection{Plant Material}

Opuntia young cladodes were collected from the CRUCEN-UACh Opuntia spp. germoplasm bank, an Agrobotanical garden located in southwest Zacatecas city, Mexico, in the "El Orito" locality $\left(22^{\circ} 44.7^{\prime}\right.$ North latitude and $102^{\circ} 36.4^{\prime}$ West length). Five species were selected from the wildest $O$. streptacantha, continuing with variants of $O$. hyptacantha and $O$. megacantha, following with $O$. albicarpa and the most domesticated variant, the $\mathrm{O}$. ficus-indica. The donor Opuntia plants were grown under the same natural environmental conditions (temperature, precipitation and soil).

Opuntia young cladodes were collected on april 2010. The selection of 15-25 cm of length young cladodes was according to Ramirez-Tobias et al. [19]. Two young cladodes from each species were collected from three different plants (Supplementary Fig. S1). Cladodes samples were transferred in an ice-container to the laboratory where they were thoroughly rinsed with distilled water, dry in paper towels and stored at $-80{ }^{\circ} \mathrm{C}$. Frozen samples were freeze-dried and grounded (KRUPS GX4100 grinder) to obtain a fine powder. Powder samples were stored at $-80^{\circ} \mathrm{C}$ until use.

\subsection{Proximate composition and phenolic compounds quantification}

Total protein content $(\mathrm{N} \times 6.25)$ was determined by the micro-Kjeldhal method [20], fat was determined by the Soxhlet method [20], and crude fiber contents were determined following the AOAC methods [20]. Total soluble sugars were determined using the anthrone- $\mathrm{H}_{2} \mathrm{SO}_{4}$ reagent method [21]. Dextrose was used as a reference compound and results were expressed as $\mathrm{mg}$ of dextrose $\mathrm{g}^{-1}$ of sample. All determinations were analyzed at in triplicates. 
The phenolic compounds extraction was carried out according to GuevaraFigueroa et al. [22]. Briefly $1 \mathrm{~g}$ of sample was mixed with $100 \mathrm{~mL}$ of absolute ethanol pre-chilled at $-20{ }^{\circ} \mathrm{C}$. suspension was incubated under agitation at $4{ }^{\circ} \mathrm{C}$ for $2.5 \mathrm{~h}$ and centrifuged at $13000 \mathrm{~g}$ at $4 \stackrel{\circ}{\circ}$. Supernatants were filtered through 0.45 $\mu \mathrm{m}$ filter (Whatman). The ethanolic extract $(20 \mu \mathrm{L})$ was added to $1.58 \mathrm{~mL}$ of MilliQ water and mixed. Then $300 \mathrm{~mL}$ of $20 \% \mathrm{Na}_{2} \mathrm{CO}_{3}$ and $100 \mu \mathrm{L}$ of Folin-Ciocalteu phenol reagent were added and the mixture was allowed to stand for $2 \mathrm{~h}$ at room temperature. Absorption of the solution was read at $765 \mathrm{~nm}$ in a UV-Vis spectrophotometer (Varian Cary, Palo Alto, CA, USA). Total phenolic content was expressed as $\mu \mathrm{mol}$ of Gallic acid equivalents $\mathrm{g}^{-1}$ of sample. All determinations were performed in triplicates. For flavonoid quantification, $15 \mu \mathrm{L}$ of ethanolic extract were diluted $735 \mu \mathrm{L}$ of MiiliQ water and mixed with $750 \mu \mathrm{L}$ of $2 \% \mathrm{AlCl}_{3}$ solution. After $10 \mathrm{~min}$, the absorbance of the mixture was read at $367 \mathrm{~nm}$ in a UVVis spectrophotometer (Varian Cary). Quercetin was used as a reference standard and results were expressed as $\mu \mathrm{mol}$ Quercetin equivalents $\mathrm{g}^{-1}$ of sample. All determinations were performed in triplicates.

\subsection{Protein extraction and quantification}

Opuntia samples ( $2 \mathrm{~g}$ ) were washed with ethanol (twice) and then three times with acetone (containing $0.2 \%$ DTT). In each step the solution was eliminated by centrifugation at $4{ }^{\circ} \mathrm{C}$ for $15 \mathrm{~min}$ at $13000 \mathrm{~g}$. Washed samples were homogenized, using a mortar and pestle on ice bath, with $15 \mathrm{~mL}$ of extraction buffer containing $100 \mathrm{mM}$ Tris- $\mathrm{HCl}$ ( $\mathrm{pH} 8.0), 1.5 \mathrm{mM}$ potassium chloride, $10 \mathrm{mM}$ dithiothreitol, $1 \mathrm{mM}$ phenylmethylsulfonyl fluoride, $0.1 \%$ SDS, followed by centrifugation at $4{ }^{\circ} \mathrm{C}$ for 20 $\min$ at $13000 \mathrm{~g}$. Proteins were precipitated by the addition of three vol of $0.1 \mathrm{M}$ 
ammonium acetate (in methanol) per vol of extract; samples were kept at $-20^{\circ} \mathrm{C}$ overnight. Proteins pellets were recovered by centrifugation at $4{ }^{\circ} \mathrm{C}$ for $20 \mathrm{~min}$ at $13000 \mathrm{~g}$ and washed with $0.1 \mathrm{M}$ ammonium acetate (once) and three times with acetone (containing $0.2 \%$ DTT), and centrifuged for $15 \mathrm{~min}$ as indicated above. All solvents were used pre-chilled at $-20^{\circ} \mathrm{C}$. Pellets were allowed to dry and resuspended in $0.1 \mathrm{M}$ Tris- $\mathrm{HCl}(\mathrm{pH} 8.0)$ and protein concentration was determined using the Protein Assay kit (Bio-Rad, Hercules, CA, USA), using BSA as standard. Triplicates of extractions were carried out.

\subsection{Protein preparation by 1-DE and shotgun analysis}

For the shotgun analysis, solubilized proteins $(10 \mu \mathrm{g})$ were mixed with Laemmli sample buffer and loaded onto 12\% SDS-PAGE. Electrophoretic migration was performed to fractionate the protein samples of each cultivar into gel lines of $40 \mathrm{~mm}$ long. Gels were colloidal coomassie blue stained and visualization was performed in a Pharos FX Plus (Bio-Rad). Each line was cut in 10 gel bands of similar size and distained, reduced and alkylated. Digestion of proteins by the trypsin and the extraction of resulting peptides were performed as in Gautier et al. [23].

The resulting peptides were analyzed by nanoLC-MS/MS using an Ultimate3000 system (Dionex, Amsterdam, The Netherlands) coupled to an LTQOrbitrap Velos mass spectrometer (Thermo Fisher Scientific, Bremen, Germany). Five $\mu \mathrm{L}$ of each sample were loaded on a C18 precolumn (300 $\mu \mathrm{m}$ inner diameter $X 5 \mathrm{~mm}$; Dionex) at $20 \mu \mathrm{L} \min ^{-1}$ in $5 \%$ acetonitrile, $0.05 \%$ TFA. After 5 min of desalting, the precolumn was switched online with the analytical C18 column (75 $\mu \mathrm{m}$ inner diameter X $15 \mathrm{~cm}$; PepMap 8, Dionex) equilibrated in $95 \%$ solvent $A$ (5\% 
acetonitrile, $0.2 \%$ formic acid) and $5 \%$ solvent $B(80 \%$ acetonitrile, $0.2 \%$ formic acid). The peptides were eluted using a 5 to $50 \%$ gradient of solvent B during 105 $\min$ at $300 \mathrm{~nL} \mathrm{~min}^{-1}$ flow rate. The LTQ-Orbitrap Velos was operated in datadependent acquisition mode with the XCalibur software. Survey scan MS were acquired in the Orbitrap on the 300-2000 $\mathrm{m} \mathrm{z}^{-1}$ range with the resolution set to a value of 60,000 . The 20 most intense ions per survey scan were selected for CID fragmentation, and the resulting fragments were analyzed in the linear trap (LTQ). Dynamic exclusion was employed within $60 \mathrm{~s}$ to prevent repetitive selection of the same peptide. Protein identification was carried out according to Stanislas et al. [24].

\subsection{Database search and data validation}

The Mascot Daemon software (version 2.3.2; Matrix Science, London, UK) was used to perform database searches, using the Extract_msn.exe macro provided with Xcalibur (version 2.0 SR2; Thermo Fisher Scientific) to generate peaklists. The following parameters were set for creation of the peaklists: parent ions in the mass range 400-4500, no grouping of MS/MS scans, and threshold at 1000. A peaklist was created for each analysed fraction (i.e., gel slice), and individual Mascot (version 2.3.01) searches were performed for each fraction. The data were searched against "Viridiplantae" entries in Uniprot protein database.

Carbamidomethylation of cysteine was set as a fixed modification and oxidation of methionine was specified as variable modification. Specificity of trypsin digestion was set for cleavage after Lys or Arg, and one missed trypsin cleavage site was allowed. The mass tolerances in MS and MS/MS were set to 5 ppm and 0.6 Da, respectively, and the instrument setting was specified as "ESITrap." To calculate the false discovery rate (FDR), the search was performed 
using the "decoy" option in Mascot. Mascot results were parsed with the in-house developed software Mascot File Parsing and Quantification (MFPaQ) version 4.0 [25], thus peptide identifications extracted from Mascot result files were validated at a final peptide FDR of $1 \%$. Peptide matches were validated if their score was greater than the Mascot homology threshold (when available, otherwise the Mascot identity threshold was used) for a given Mascot $p$ value. The FDR at the peptide level was calculated as described in Navarro and Vazquez [26]. Using this method, the $p$ value was automatically adjusted to obtain a FDR of $1 \%$ at the peptide level. Validated peptides were assembled into proteins groups following the principle of parsimony (Ocam's razor), which involves the creation of the minimal list of protein groups explaining the list of peptide spectrum matches. Protein groups were then rescored for the protein validation process. For each peptide match belonging to a protein group, the difference between its Mascot score and its homology threshold (or identity threshold) was computed for a given $p$ value (automatically adjusted to increase the discrimination between target and decoy matches), and these "score offsets" were then summed to obtain the protein group score. Protein groups were validated based on this score to obtain a FDR of $1 \%$ at the protein level (FDR = number of validated decoy hits/(number of validated target hits + number of validated decoy hits) X 100).

\subsection{Protein grouping and data quantitation}

Quantification of proteins and peptides was performed using the label-free module implemented in the MFPaQ v4.0.0 software (http://mfpaq.sourceforge.net/). General procedures of this software are detailed in Gautier et al. [23]. For each cultivar, quantification of peptide ions was performed in four replicates, two times for the first extraction and two times for the second 
extraction. This method was based on calculated XIC area values and in the instance where the peptide was identified in several electrophoresis gel fractions; the XIC area values were summed. The similar peptide sequences with identical mass and containing the L, (leucine) or I (isoleucine) amino acid at the same position were not taken into consideration for the quantitation. To perform the normalization of peptide quantitation in the four replicates, the ratios of the XIC area values were calculated for all the extracted signals between one replicates and the three others and the median of the ratios was used as a normalization factor. The sum value of the peptide XIC area values of the four replicates was assigned at the corresponding protein as a protein abundance index (PAI).

Protein identifications, PAI and peptide quantitation were exported from MFPaQ and uploaded to the software Protein Center (Thermo Fisher Scientific, http://www.proxeon.com/productrange/data_interpretation/introduction/index.html) in the aim of the comparison of the five species. The proteins were assembled in a same group if they have at least one peptide in common. The anchors of the groups are the proteins, which have the best PAI and a maximal number of peptides. Only the groups were taken in consideration for the comparisons between the species.

\subsection{Statistical analysis.}

Data of total protein, fat, fiber ash, sugar, phenolic, and flavonoid compounds were expressed as mean values of triplicates. One-way analysis of variance (ANOVA) was performed with significant differences among means determined by the Tukey's test at $p \leq 0.05$. 


\section{Results}

\subsection{Opuntia morphological characteristics}

It is known that within the Opuntia genus, the presence of spines, the number of spines/areole, and the number of areoles may differ drastically in different growing regions [27]. For this reason, all donor plants were collected from "Opuntario" located at southwest Zacatecas city, Mexico, where natural growing conditions (arid soil, low precipitation, high temperature), were the same for all species therefore molecular changes will be only for intrinsic characteristics of each species.

Morphological differences were observed among Opuntia species, the wildest O. streptacantha had more spines in cladodes and more circular shape while $O$. ficus-indica, the domesticated specie, presented few, small and soft spines, and elongated shape (Fig. 1 and Supplementary Table S1). However, it has been described that the presence of spines in the cladodes is an inadequate feature to discriminate $O$. ficus-indica from other arborescent Opuntias [28] suggesting that changes at molecular level may be a key for Opuntia classification.

The Opuntia cladodos macromolecular composition (Table 1) showed that $O$. hyptiacantha presented the lower total protein concentrations (10.5\%) but has the higher fat $(0.94 \%)$ contents, in regard to crude fiber contents the wildest $O$. streptacantha and $O$. hyptiacantha presented the highest values $(6.52 \%$ and $6.58 \%$, respectively) while domesticated Opuntia ficus-indica has the higher protein content but the lowest crude fiber. Fiber is an important characteristic due that some of medicinal effects claimed for Opuntia are attribute to the fiber content [29]. Synthesis of osmolytes is one important mechanism for plant tolerance to abiotic stress and soluble sugars content was determined. It was observed that $O$. 
megacantha followed by $O$. streptacantha had the highest accumulation of total sugars (103.7 $\mathrm{mg} \mathrm{g}^{-1}$ and $61.0 \mathrm{mg} \mathrm{g}^{-1}$, respectively), while the lowest values were detected in O. albicarpa, the semi-domesticated species (Table 1). Phenolic and flavonoids compounds have been also claimed as the molecules responsible of the claimed Opuntia medicinal characteristics. Total phenolic compounds (Table 1) were higher in the wildest species 0 . streptacantha $(65.1 \mu \mathrm{mol}$ of GA g-1), while were not differences in flavonoids contents between the wildest $O$. streptacantha and the most domesticated $O$. ficus-indica. These results show that metabolism regulation among Opuntia species is different.

\subsection{Opuntia shotgun analysis}

Opuntia cladodes proteins were separated by SDS-PAGE, the gel was divided in 10 bands that were excised and digestion of each band was performed (Supplementary Fig. S2). The resulting tryptic-digested fragments were analyzed by nanoLC-MS/MS, database searches using MS/MS sequencing data were performed with MASCOT and the results files were parsed and validated based on target decoy calculated FDRs, set at $5 \%$ for peptides and $1 \%$ for proteins.

Into each cultivar, proteins with at least $60 \%$ in sequence identity were grouped. Populus trichocarpa proteome was used to compare the groups; this species was selected as reference because the most numbers of orthologs sequences were identified (Table 2). The protein family database (PFAM) allowed defining those proteins that were specific in the analyzed Opuntia species and those who were particularly abundant (Supplementary Files S1-S5).

\subsection{Proteins overrepresented or underrepresented in the wild species compared to $O$. ficus-indica}


Identified peptides were quantified using the MS signal in the MFPAQ software. The value assigned to each peptide for each variety and each replicate is the sum of the intensities detected in each region of the electrophoresis track. These values were normalized on the basis of the replicate where the sum of intensities of all peptides is the highest. The median ratios between replicates were used. The median was calculated only using the values of the quantified peptides in four replicates. The ratio of the average intensities of the replicates of the wild variety with that of $O$. ficus-indica was used to evaluate the up-accumulation or downaccumulation of the peptide. Student's T-test, taking into account the four replicates, was applied to define the $p$-value that must be less than 0.05 if the difference is significant. This test was applied after the missing values have been replaced. These missing values were calculated by taking into account the maintenance of the coefficient of variation of the population. Each wild species was compared to the $O$. ficus-indica variety and a quantitative ratio is calculated if the following criteria are in agree: a) at least two common peptides should be present on the same homologous protein, b) at least one of the peptides has been identified in three replicates in one of the five species, c) at least each peptide is quantified 2 times in the wild species and the $O$. ficus-indica.

The overrepresented proteins in the wild type variety proteins were selected if all quantified peptides had an intensity ratio greater than 1 between the wild type and $O$. ficus-indica and if at least two of them are significantly different ( $p$-value $<$ 0.05). The underrepresented proteins were selected if all peptides had a ratio less than 1 , and if 2 of them were significantly different $(p$-value $<0.05)$. The differentially represented proteins have an abundance ratio index corresponding to the average ratio of all the quantified peptides. The lists of the overrepresented 
proteins (excess proteins) and those of the underrepresented proteins (protein loss) were imported into Protein Center for functional analysis after grouping according to $60 \%$ of sequence identity.

Shotgun analysis revealed that the domestication greatly influences the protein composition in Opuntia cladodes. It was evident that the wildest species $(O$. streptacantha and $O$. megacantha) contain specific proteins or in excess versus $O$. ficus-indica (Supplementary Files S6-S10).

\subsection{Specific proteins and peptides}

Filtered proteins (60\% identity) from 0 . streptacantha, O. megacantha, $O$. hyptiacantha, and $O$. albicarpa species were compared with the identified proteins from O. ficus-indica. A grouping was performed when the proteins have a common peptide at least between the two considered species. The groups of the wild variety that contain no identical peptide to $O$. ficus-indica were noted as specific. Then, these specific proteins were grouped again according to $60 \%$ sequence identity (Supplementary Files S11-S15). All the identified peptides of a wild species were compared to the total list of peptides from the $O$. ficus-indica. The list of peptides that were absent in the proteins of $O$. ficus-indica is show in the Supplementary Files S16-S19, these peptides may belong to specific or nonspecific proteins.

\section{Discussion}

Classification of Opuntia proteins according to their biological processes (Fig. 2), it was observed that almost the half of the proteins corresponded to metabolic process, and the wildest species (O. streptacantha, O. hyptiacantha, and $O$. megacantha) contained the higher percentages (47.2\% to $48.4 \%)$, while the 
domesticated O. albicarpa and O. ficus-indica, had the lowest values $(44.4 \%$ and $45.8 \%$, respectively). Interestingly, proteins related with defense and responses to stimulus were more represented in $O$. streptacantha (13.1\%) and O. hyptiacantha (13.9\%). According to its molecular function, differences were observed in protein related with catalytic role (34.4\% to $35.6 \%$ ), followed by proteins with DNA, RNA, and nucleotide binding function ( $20.0 \%$ to $22.9 \%)$, metal binding proteins were also well represented in all Opuntia species (Supplementary Fig. S3).

\subsection{Carbon metabolism is up-regulated in wild species}

A considerable number of proteins involved in carbon metabolism were preferentially overrepresented in wild species, in particular the key enzymes involved in the regulation of glycolysis. Enolase showed significantly higher accumulation levels in $O$. hyptiacantha, while two orthologs of glycheraldehyde-3phosphate dehydrogenase were detected in O. streptacantha (Table 3 and Supplementary Files S16 to S19). At least five orthologs of Fructose-1,6bisphosphate aldolase (FBA), were detected in differential accumulation among Opuntia species, one FBA protein species was highly accumulated in $O$. hyptiacantha. FBA is another key enzyme in the glycolytic pathway that catalyses the reversible reaction by converting fructose-1,6-bisphosphate (FBP) into dihydroxyacetone phosphate (DHAP) and glyceraldehyde 3-phosphate (G3P), two key intermediates for oil biosynthesis [30]. This finding correlates with the observation that $O$. hyptiacantha has the highest fat content (Table 1).

The accumulation of pyruvate kinase suggests higher energy consumption in wild species, especially in $O$. hyptiacantha. Aldehyde dehydrogenase (ADH) is an important enzyme that play important role in mitigating oxidative/electrophilic 
stress when plants are exposed to unfavourable environmental conditions was over-represented in 0 . hyptiacantha. The overexpression in transgenic tobacco plants with $A D H$ gene from Syntrichia caninervis (ScALDH21) enhanced drought and salt tolerance suggesting that could be a good candidate gene for molecular breeding of salt- and drought-tolerant plants [31].

Mitochondrial metabolic enzymes, as energetic generators and/or targets of signals, are important players in the distribution of intermediates between catabolic and anabolic pathways. The Krebs metabolism was less active in 0 . megacantha and $O$. albicarpa by the down-accumulation of aconitase, which catalyzes the reversible isomerization of citrate to isocitrate (Table 3). The 2- oxoglutarate dehydrogenase complex (OGDHC), which occupies an amphibolic branch point in the cycle, where the energy-producing reaction of the 2-oxoglutarate degradation competes with glutamate (Glu) synthesis was overrepresented in $O$. streptacantha. It has been shown that inhibition of OGDHC in tomato (Solanum lycopersicum) substantially reduces both photosynthetic and respiratory metabolism and plant development connecting carbon-nitrogen interactions $[32,33]$.

\subsection{Photosynthesis related-enzymes}

The high Opuntia species productivity is related with their use of the crassulacean acid metabolism (CAM) photosynthetic pathway. CAM plants maximizes the water use efficiency by concentrating $\mathrm{CO}_{2}$ around ribulose-1,5bisphosphate carboxylase/oxygenase (RuBisCO), favoring carboxylase activity. At least three isoforms of RuBisCO were detected, one ortholog was up-accumulated in O. streptacantha and another was down-accumulated in O megacantha (Table 
3). The most distinctive features of CAM organisms are the nocturnal $\mathrm{CO}_{2}$ uptake and fixation by phosphoeno/pyruvate carboxylase (PEPC) PEPC as well the pyruvate phosphate dikinase (PPDK) were up-accumulated in O. streptacantha suggesting an increase carbon fixation compared with the other Opuntia species. In darkness, also two energy-consuming enzymes of the Calvin cycle, the phosphoribulokinase (PRK) and glycerladeyde-3-phosphate dehydrogenase (GAPDH) are crucial enzymes for the global balance of the photosynthetic process under different environmental conditions [34]. Two protein species of PRK were detected, one up-accumulated in O. streptacantha and the second downaccumulated in $O$. megacantha.

Enzymes related with starch metabolism such as alpha1,4-glucan phosphorylase, UDP-G glucose 6-dehydrogenase and sucrose synthase (SUS) were also detected. Two orthologs of SUS were up-accumulated in $O$. streptacantha, while highest accumulation of alpha1,4-glucan was observed in $O$. hyptiacantha (Table 3). Studies on gene expression and evolution have provided new insights into the role of positive selection in the intra species divergence [35], and then the analysis of SUS could be a good candidate gene-protein to get information about the true domestication route of Opuntia species. An increase of SUS expression has been correlated with an increase in cellulose [36], this correlate with the detection of cellulose biosynthetic process protein in $O$. hyptiacantha and the higher fiber contents detected in this species (Table 1) as well with reports indicating that that wild species are higher in fiber contents $[22,37]$.

In relation with the higher glucose metabolism in wild Opuntia species, enzymes related with the photosystem II (CP43, CP47, Lhcb, OEC, Cytb6, Cytf) and 
photosystem I (PA700) were up-accumulated in wild species. Both CP43 and CP47, core antenna proteins of PSII, contain six trans-membrane helices, which binds 13 and 16 chlorophyll a molecules, respectively. The electron flow through Cytb6/f complex is considered to be a key rate-limiting step for RuBisCO regeneration [38], increasing CytB6/f content may be a useful biomolecular target for enhancing leaf photosynthesis for improved crop yield [39]. These results show that Opuntia wild species, the best adapted to environmental stresses, have higher accumulation of photosystem proteins subunits.

\subsection{One-carbon and nitrogen metabolism}

One carbon (C1) metabolism is essential to all organisms, in plants it supplies the $\mathrm{C} 1$ units to synthesize essential molecules biosynthetic and regulatory compounds, including proteins, nucleic acids, pantothenate, and methylated compounds such as lignin, alkaloids, and betaines [40]. It has been suggested that depletion of one-carbon tetahydrofolate (TFH) pools and methionine could effectively and specifically block protein translation, as well as alter DNA methylation and synthesis [41]. Serine hydroxymetil transferase (SHMT) is important for $\mathrm{C} 1$-metabolism and photorespiration in higher plants for tis participation in plant growth and development, and resistance to biotic and abiotic stresses [42]. S-adenosyl-L-methionine synthase (SAMS) catalyze the biosynthesis of SAM, which is a precursor for ethylene and polyamines, and a methyl donor for a number of biomolecules. SHMT and SAMS were upaccumulated in O. streptacantha (Table 3). S-adenosyl cysteine synthase (SACS) through the route of DNA methylation was also overrepresented in $O$. streptacantha, Transgenics Arabidopsis lines transformed with SAMS from Solanum brevidens (SbSAMS) exhibited higher salt and drought stress tolerance 
[43]. The enzyme $\Delta$-1-pyrolidine synthase was also over represented in wild species, suggesting a higher accumulation of proline. Thiamine thiazole (THI1) has been associated with heat tolerance in rice [44] and was up-accumulated in $O$. megacantha.

Glutamine synthetase (GS), found overrepresented in $O$. streptacantha and $O$. hyptiacantha (Table 3). GS plays a crucial role in plant growth by assimilating ammonium from the soil and in the re-assimilation of photorespiratory ammonium released during photorespiration [45]. GS has been shown to play role in water use efficiency by being responsive to drought and salt stress [46], its deficiency decline photorespiration and increase ammonium concentrations significantly, therefore, causing significant decrease in photosynthesis in barley $[47,48]$, by contrary its overexpression increase photorespiratory capacity in wheat [49] and rice under osmotic stress [50].

\subsection{Secondary metabolism}

Plant geranylgeranyl hydrogenase (CHLP) reduces free geranylgeranyl diphosphate to phytyl diphosphate, which provides the side chain to chlorophylls, tocopherols, and plastoquinones [51]. CHLP and protochlorophyllide reductase (POR), enzymes related with chlorophyll synthesis were detected up-accumulated in wild Opuntia species (O. streptacantha and O. hyptiacantha) as well the was upaccumulated in the wild Opuntia, these results correlate with the observation that these species contain more chlorophyll-binding proteins such as Lcab (Table 3).

It is interesting to note that enzymes required for monlignol biosynthesis such as phenylalanine ammonia-lyase (PAL), caffeoyl-CoA O-methyltransferase, cinnamoyl alcohol dehydrogenase (CAD), and sinapyl alcohol dehydrogenase 
[52], were detected in wildest Opuntia species (Supplementary Files S6-S10), which correlates with the observation that in this species was detected highest phenolic compounds accumulation (Table 1).

\subsection{ROS Scavenging and oxide-reduction proteins}

The SOD family of proteins are essential enzymes of ascorbate glutathione cycle and act as the first level of defense controlling concentrations of two important ROS, superoxide radicals and hydrogen peroxide. In the second line of defense, peroxidase-class enzymes, such as catalase (CAT), ascorbate peroxidase (APx) play key functions in the hydrogen peroxide detoxification reducing ROS to non-damaging concentration [53]. SOD was found accumulated in O. streptacantha, while CAT and two orthologs of APx were more representative in O. hyptiacantha (Table 3). Zhang et al. [54] reported that the more tolerance of Arabidopsis to severe salinity was due to the higher CAT, peroxidases as well proline accumulation.

Thioredoxin (Trx), redox-sensitive proteins, play crucial roles in the regulation of cellular processes in plants [55buchanan]. It has been reported that some of the Trx targets are PRK, GAPDH, and FBP [56]. Trx was up-accumulated in $O$. hyptiacantha, that correlate with the up-accumulation of FBP (Table 3).

Lipoxygenase (LOX) are enzymes related with the metabolism of several regulators named oxylipins, molecules that are directly associated with defense reactions in conditions of biotic and abiotic stresses as well as with the regulation of plant growth, propagation and senescence [57]. LOX was up-accumulated in $O$. streptacantha, 
The glycolate oxidase (GO; S-2-hydroxyacid oxidase), a flavin mononucleotide (FMN)-dependent enzyme, was up-accumulated in O. streptacantha (Table 3). Transgenic tobacco plants with reduced levels of GO exhibited decrease photosynthetic electron transport rates in high light conditions [58].

\subsection{Regulatory and Heat shock proteins}

Protein ubiquitination, a critical post-translational regulatory mechanism, plays an important role in plant tolerance against various biotic and abiotic stresses [5961]. Proteins related with the regulatory systems were detected in all Opuntia species (Fig. 3), However, O. streptacantha presented up-accumulation of several subunits of (Table 3). It has been reported that altering expression of $26 \mathrm{~S}$ proteasome subunits may affect the amount as well as the activity of the $26 \mathrm{~S}$ proteasome and could be related with flooding tolerance in soybean [62] and also in plant defense responses to pathogens during plant-pathogen interactions [63].

The study of 14-3-3 proteins is taking attention due to the increasing evidences that suggests that in plants they play important functions [64]. Some 14-3-3 subunits strongly interact with proteins involved in carbon and nitrogen metabolism, where nitrate reductase and SUS are some of the more extensively characterized 14-3-3 client proteins [65] and its overexpression has been related to the increased drought tolerance in rice [66]. 14-3-3 proteins also have been reported to be involved in the activation of plasma membrane $\mathrm{H}^{+}$-ATPase [67]. Interestingly, in all Opuntia species were identified different protein species of 143-3 proteins (Supplementary Files S16-S19) suggesting the importance of these proteins in Opuntia growth and development. 
Molecular chaperone/heat-shock proteins (HSPs) are responsible for protein stabilization, proper folding, assembly and translocation under both optimum and adverse growth conditions. A great variety of $\operatorname{HSPs}(90,60,70,101,902-1,902-$ 1), Hsc70, and HSP40s also known as DnaJ proteins were identified in all Opuntia species. DnaJ proteins as co-chaperones have critical functions in biotic and abiotic stress responses, but their biological functions remain largely uninvestigated. The overexpression of DnaJ from Solanum lycopersicum (tomato) improved the resistance to the pathogen Ralstonia solanacearum in transgenic tobacco [68]. In wild O. streptacantha was detected the up-accumulation one cytosolic chaperonin and Hsp90, while in O. hyptiacantha one Hps was upaccumulated. Recently studies have indicated that $H s p 90$ gene could be a novel candidate capable of influencing the chip colour of potato tubers [69].

\subsection{Nuclear Proteins, transcription, and translation factors}

Ribosomal proteins 60S (L7 and L12), 40S (S8, S14) were identified in wild species in higher concentrations, especially in $O$. streptacantha and $O$. hyptiacantha (Table 3). The increased production of ribosomal proteins, suggest an adaptation of wild species to survive in conditions of highest UV exposition as reported in Zea mays [70]. The elongation eF2 and translation initiation factor elF4A were down-accumulated in $O$. megacantha (Table 3). elF4F, which is composed of elF4E, elF4A, and elF4G, is required to promote $40 \mathrm{~S}$ subunit binding to an mRNA [71].

\subsection{Membrane trafficking and transport}


Under hypersaline conditions, several plant response which includes cell-wall hardening, osmoregulatory process, and the over-expression of the tonoplast specific intrinsic protein pyrophosphate-energized inorganic pyrophosphatase $\left(\mathrm{H}^{+}-\right.$ PPase), suggesting that vacuoles are engaged in $\mathrm{Na}+$ sequestration accordingly with a high capacity of proton pumping and $\mathrm{Na}+$ uptake via the $\mathrm{Na}+\mathrm{H}+$-antiporter in seagrasses and halophytes [72-74]. An up- accumulation of inorganic pyrophosphatase, V-type proton ATPase, and vacuolar $\mathrm{H}^{+}$-ATPase were detected in wild O. streptacantha but down-accumulated in O. megacantha (Table 3).

Two isoforms of GTPase-sar1 were identified in Opuntia, one was upaccumulated in O. hyptiacantha and the second in O. megacantha (Table 3). Recently it has been reported that CPSAR1 protein, identified in chloroplast vesicles, play an important role for normal thylakoid formation [75]. In rice Sar acts as a molecular switch to regulate the assembly of coat protein complex II, which exports secretory protein form the ER to the Golgi apparatus [76]

Endocytosis involves the internalization or uptake of plasma membrane (PM) proteins, lipids, and extracellular molecules into the cell. Clathrin-mediated endocytosis (CME) is the major route in plants [77-78], and was observed upaccumulated in O. streptacantha. CME has been shown to be a major endocytic pathway in Arabidopsis and has been implicated in the signalling network associated with the recognition of microbes by plants [76].

\section{CONCLUSIONS}

This work represents the first large-scale proteomics analysis of Opuntia species, important plants that grows under extreme environmental conditions and with several medicinal properties. Although Opuntia genome has not been 
reported, proteomics has proved to be a valuable tool to identify proteins and their differential accumulation along domestication. A brief schematic representation of protein changes, when comparing with the most domesticated $O$. ficus-indica, is shown in Fig. 4. Our data have shown that the wildest species 0 . streptacantha and $O$. hyptiacantha presented the most up-accumulation of proteins in cladodes in relation to the most domesticated $O$. ficus-indica. Accumulation of enolase in $O$. hyptiacantha could correlate with the observed higher fat content in cladodes. Accumulation of SUS in O. megacantha correlated with the higher fiber contents presented in this species. Enzymes of the 1C-metabolism were observed up accumulated in wild species suggesting that regulatory molecules such as polyamines, ethylene, and also methylation processes are involved as important mechanisms of plant responses to environmental conditions.

Finally our proteomic data indicates a correlation between domestication grade and protein abundance showing the Opuntia molecular changes through domestication, information that will help to understand the agronomic and nutraceutical characteristics of wild and domesticated Opuntia species.

\section{Conflict of interest:}

The authors declare that they do not have any conflict of interest.

\section{Acknowledgments}

MG Astello-García thanks to CONACyT fellow N 46549. Thank to Bilateral Mexico-France Project Collaboration "Biopuntia" grant No. 142873. Thank to Dr. Clemente Gallegos from Opuntario-Zacatecas for Opuntia samples. 


\section{References}

[1] Harlan JR. Agricultural origins: Centers and Noncenters. Science 1971;174:468-74.

[2] Hawkes J.G. The diversity of crop plants. Harvard University Press, London. 1983.

[3] Casas A, Pickersgill B, Caballero J, Valiente-Banuet A. Ethnobotany and domestication in Xoconochtli, Stenocereus stellatus (Cactaceae), in the Tehuacán Valley and La Mixteca Baja, México. Economic Bot. 1997:3:279-92.

[4] Arellano E, Casas A. Morphological variation and domestication of Escontria chiotilla (Cactaceae) under silvicultural management in the Tehuacán Valley, Central Mexico. Gen Resour Crop Ev. 2003;50:439-53.

[5] Guillén S, Terrazas T, De la Barrera E, Casas A. Germination differentiation patterns of wild and domesticated columnar cacti in a gradient of artificial selection intensity. Gen Res Crop Evol. 2011;58:409-23.

[6] Griffith MP. The origins of an important cactus crop, Opuntia ficus-indica (Cactaceae): New molecular evidence. Am J Bot. 2004;91:1915-21.

[7] Anaya-Pérez M.A. History of the use of Opuntia as forage in Mexico. In: Cactus (Opuntia spp.) as forage. FAO Plant Production and Protection Paper, 169, 2002.

[8] Anderson EF. The cactus family. In: Plant Systematics and Evolution, Paull. Forster (Ed.) Timber Press, Portland 228, pp 776, 2001.

[9] Reyes-Agüero JA, Aguirre-Rivera JR, Flores-Flores JL. Variación morfológica de Opuntia (Cactaceae) en relación con su domesticación en la Altiplanicie Meridional de México. Interciencia 2005;30:476-84.

[10] Pujol B, Mühlen G, Garwood N, Horoszowski Y, Douzery EJ, McKey D. Evolution under domestication: contrasting functional morphology of seedlings in domesticated cassava and its closest wild relatives. New Phytol. 2005;166:305-18.

[11] Jacobs DI, Gaspari M, van der Greef J, van der Heijden R, Verpoorte R. Proteome analysis of the medicinal plant Cataharantus roseus. Planta 2005;221:690-704.

[12] Kim SI, Kim JY, Kim EA, Kwon KH, Kim KW, Cho K, et al. Proteome analysis of hairy root from Panax ginseng C.A. Meyer using peptide fingerprinting, internal sequencing and expressed sequence tag data. Proteomics 2003;3:2739-92.

[13] Huerta-Ocampo JA, Barrera-Pacheco A, Mendoza-Hernández CS, EspitiaRangel E, Mock HP, Barba de la Rosa AP. Salt stress-induced alterations in the root of proteome of Amranthus cruentus L. J Proteome Res. 2014;13:3607-27.

[14] Hu G, Koh J, Yoo M-J, Grupp K, Chen S, Wendel JF. Proteomics profiling of developing cotton fibers from wild and domesticated Gossypium barbadense. New Phytol. 2013;200:570-82.

[15] Hu G, Koh J, Yoo M-J, Pathak D, Chen S, Wendel JF. Proteomics profiling of fiber development and domestication in upland cotton (Gossypium hirsutum L.) Planta 2014;240:1237-1251.

[16] Mensack MM, Fitzgerald VK, Ryan EP, Lewis MR, Thompson HJ, Brick MA. Evaluation of diversity among common beans (Phaseolus vulgaris L.) from two centers of domestication using "omics" technologies. BMC Genomics 2010;11:686. 
[17] Capriotti AL, Borrelli GM, Colapiocchioni V, Papa R, Piovesana S, Samperi R, Stampachiacchiere S., Lagná A. Proteomic study of a tolerant genotype of durum wheat under salt-stress conditions. Analy Bioanal Chem. 2014;406:1423-35.

[18] Castillejo MA, Staudinger C, Egelhofer V, Wienkoop S. Medicago truncatula proteomics for systems biology: novel rapid shotgun LC-MS approach for relative quantification based on full-scan selective peptide extraction (Selpx). Methods Mol Biol 2014;1072:303-13.

[19] Ramírez-Tobías HM, Reyes-Agüero JA, Pinos-Rodríguez JM, Aguirre-Rivera JR. Effect of the species and maturity over the nutrient content of cactus pear cladodes. Agrociencia 2007;41:619-26.

[20] AOAC. Official Methods of Analysis, $18^{\text {th }}$ ed. Association of Official Analytical Chemists, Washington, DC. 2007.

[21] Irigoyen JJ, Einerich DW, Sánchez-Díaz M. Water stress induced changes in concentrations of proline and total soluble sugars in nodulated alfalfa (Medicago sativa) plants. Physiol Plant. 1992;84:55-60.

[22] Guevara-Figueroa T, Jiménez-Islas H, Reyes-Escogido ML, Mortensen AG, Laursen BB, Lin Li-W, et al. Proximate composition, phenolic acids, and flavonoids characterization of commercial and wild nopal (Opuntia spp.). J Food Compost Anal. 2010;23:525-32.

[23] Gautier V, Mouton-Barbosa E, Bouyssié D, Delcourt N, Beau M, Girard JP, Cayrol C, Burlet-Schiltz O, Monsarrat B, Gonzalez de Peredo A. Label-free quantification and shotgun analysis of complex proteomes by one-dimensional SDS-PAGE/NanoLC-MS: evaluation for the large scale analysis of inflammatory human endothelial cells. Mol Cell Proteomics 2012;11:527-39.

[24] Stanislas T, Boyssie D, Rossignol M, Vesa S, Fromentin J, Morel J, Pichereaux C., Monsarrat B. Simon-Plas F. Quantitative proteomics reveals a dynamic association of proteins to detergent-resistant membranes upon elicitor signalling in tobacco. Mol Cell Proteomics 2009;8:2186-98.

[25] Bouyssié D, Gonzalez de Peredo A, Mouton E, Albigot R, Roussel L, Ortega N, Cayrol C, Burlet-Schiltz O, Girard JP, Monsarrat B. MFPaQ, a new software to parse, validate, and quantify proteomic data generated by ICAT and SILAC mass spectrometric analyses: application to the proteomic study of membrane proteins from primary human endothelial cells. Mol Cell Proteomics 2007;6:1621-37.

[26] Navarro P, Vazquez J. A refined method to calculate false discovery rates for peptide identification using decoy databases. J Proteome Res. 2009;8:1792-6.

[27] Rebman JP, Pinkava DJ. Opuntia cacti of North America - an overview. Fla Entomol. 2001;84:474-83.

[28] Nieddu G, Chessa I. Distribution of phenotypic characters within a seedling population from Opuntia ficus-indica (cv."Gialla"). Acta Horticulturae 1997;438:37-43.

[29] Shetty AA, Rana MK, Pretham SP. Cactus: a medicinal food. J Food Sci Technol. 2012;49:530-6.

[30] Zeng $Y$, Tan X, Zhang L, Jiang N, Cao H. Identification and expression of fructose-1,6-bisphosphate aldolase genes and their relations to oil content in developing seeds of tea oil tree (Camellia oleifera). PLoS ONE 2014;9:e107422. 
[31] Yang H, Zhang D, Li H, Dong L, Lan H. Ectopic overexpression of the aldehyde dehydrogenase ALDH21 from Syntrichia caninervis in tobacco confers salt and drought stress tolerance. Plant Physiol Biochem. 2015;95:83-91.

[32] Araújo WL, Trofimova L, Mkrtchyan G, Steinhauser D, Krall L, Graf A, et al. On the role of the mitochondrial 2-oxoglutarate dehydrogenase complex in amino acid metabolism. Amino Acids 2013;44:683-700.

[33] Araújo WL, Tohge T, Osorio S, Lohse M, Balbo I, Krahnert I, et al. Antisense inhibition of the 2-oxoglutarate dehydrogenase complex in tomato demosntrates its importance for plant respiration and during leaf senescence and fruit maturation. Plant Cell 2012;24:2328-51.

[34] Marri L, Thieulin-Pardo G, Lebrun R, Puppo R, Zaffagnini M, Trost P, et al. CP12-mediated protection of Calvin-Benson cycle enzymes from oxidative stress. Biochimie 2014;97:228-37.

[35] Jian SY, Chi YH, Wang JZ, Zhou JX, CHENG YS, Zhang BL, Ma A, Vanitha J, Ramachandran $S$. Sucrose metabolism gene families and their biological functions. Scientific Rep. 2015;5:17583.

[36] Albrecht G, Mustroph A. Localization of sucrose synthase in wheat roots: increased in situ activity of sucrose synthase correlates with cell wall thickening by cellulose deposition under hypoxia. Planta 2003;217:252-60.

[37] Astello-Garcia MG, Cervantes I, Nair V, Santos-Díaz MS, Reyes-Agüero A, Guéraud F, Negre-Salvayre A, Rossignol M, Cisneros-Zevallos L, Barba de la Rosa AP. Chemical composition and phenolic compounds profile of cladodes from Opuntia spp. cultivars with different domestication gradient. J Food Compost Anal. 2015;43:119-30.

[38] Yamori W, Takahashi S, Makino A, Price GD, Badger MR, von Caemmerer S. The roles of ATP synthase and the cytochrome b6/f complexes in limiting chloroplast electron transport and determining photosynthetic capacity. Plant Physiol. 2011;155:956-62.

[39] von Caemmerer S, Evans JR. Enhancing C3 photosynthesis. Plant Physiol. 2010;154:589-92.

[40] Hanson AD, Roje S. One-carbon metabolism in higher plants. Annu Rev Plant Physiol Plant Mol Biol. 2001;52:119-37.

[41] Crider KS, Yang TP, Berry RJ, Bailey LB. Folate and DNA methylation: A review of molecular mechanisms and the evidence for folate's role. Adv Nutr. 2012;3:21-38.

[42] Wang D, Liu H, Li S, Zhai G, Shao J, Tao Y, et al., Characterization and molecular cloning of a serine hydroxymethyltransferase 1 (OsSHM1) in rice. J Integr Plant Biol. 2015:57:745-56.

[43] Kim SH, Kim SH, Palaniyandi SA, Yang SH, Suh JW. Expression of potato Sadenosyl-L-methionine synthase (SbSAMS) gene altered developmental characteristics and stress responses in transgenic Arabidopsis plants. Plant Physiol Biochem. 2015;87:84-91.

[44] Chen X, Zhang W, Zhang B, Zhou J, Wang Y, Yang Q, Ke Y, He H. Phosphoproteins regulated by heat stress in rice leaves. Proteome Sci. 2011;9:37.

[45] Keys AJ, Bind IF, Cornelius MJ, Lea PJ, Walsgrove RM, Milfin BJ. Photorespiratory nitrogen cycle. Nature 1978;275:741-3.

[46] Bernard SM, Habash DZ. The importance of cytosolic glutamine synthetase in nitrogen assimilation and recycling. New Phtyol. 2009;182:608-29. 
[47] Blackwell RD, Murray AJS, Lea PJ. Inhibition of photosynthesis in barley with decreased levels of chlorplastic glutamine synthetase activity. J Exp Bot. 1987;38:1799-1809.

[48] Wallsgrove RM, Turner JC, Hall NP, Kendall AC, Bright SWJ. Barley mutants lacking chloroplast glutamine synthetase-biochemical and genetic analysis. Plant Physiol. 197:83:155-8.

[49] Palatnik JF, Carrillo N, Valle EM. The role of photosynthetic electron transport in the oxidative degradation of chlorplastic glutamine synthetase. Plant Physiol. 1999;121:471-8.

[50] Hoshida H, Tanaka Y, Hibino T, Hayashi Y, Tanaka A. Takabe T, Takabe T. Enhanced tolerance to salt stress in transgenic rice that overexpresses chloroplast glutamine synthetase. Plant Mol Biol. 2000;43:103-11.

[51] Giannino D, Condello E, Bruno L, Testone G, Tartarini A, Cozza R, Innocenti $A M$, Bitonti $M B$, Mariotti $D$. The gene geranylgeranyl reductase of peach (Prunus persica [L.] Batsch) is regulated during leaf development and responds differentially to distinct stress factors. J Exp Bot. 2004;55:2063-73.

[52] Boudet AM, Kajita S, Grima-Pettenati J, Goffner D. Lignins and lignocellulosics: A better control of synthesis for new and improved uses. Trends Plant Sci. 2003;8:576-81.

[53] Duarte B, Sleimi N, Cacador I. Biophysical and biochemical constraints imposed by salt stress: learning from halophytes. Front Plant Sci. 2014;5:Article 746.

[54] Zhang B, Liu K, Zheng $\mathrm{Y}$, Wang $\mathrm{Y}$, Wang J, Liao H. Disruption of AtWNK8 enhances tolerance of Arabidopsis to salt and osmotic stresses via modulating proline content and activities of catalase and peroxidase. Int $\mathrm{J}$ Mol Sci. 2013;14:7032-47.

[55] Buchanan BB, Holmgren A, Jacquot JP, Scheibe R. Fifty years in thethioredoxin field and a bountiful harvest. Biochim Biophys Acta. $2012 ; 1820: 1822-9$.

[56] López-Calcagno PE, Howard TP, Raines CA. The CP12 protein family: a thioredoxin-mediated mediated metabolic switch?. Front Plant Sci. 2014;5:Article 9.

[57] Savchenko TV, Zastrijinaja OM, Klimov VV. Oxylipins and plant abiotic stress resistance. Biochem (Mosc). 2014:79:362-75.

[58] Zelitch I, Schultes NP, Peterson RB, Brown P, Brutnell TP. High glycolate oxidase activity is required for survival of maize in normal air. Plant Physiol. 2009;149:195-204.

[59] Pickart CM. Mechanisms underlying ubiquitination. Annu Rev Biochem. 2001;70:503-33.

[60] Devoto A, Muskett PR, Shirasu K. Role of ubiquitination in the regulation of plant defense against pathogens. Curr Opin Plant Biol. 2003;6:307-11.

[61] Hotton SK, Callis J. Regulation of cullin RING ligases. Ann Rev Plant Biol. 2008;59:467-89.

[62] Hosain Z, Khatoon A, Komatsu S. Soybean proteomics for unraveling abiotic stress response mechanism. J Proteome Res. 2013;12:4670-84.

[63] Monovarfeshani A, Mirzaei M, Sarhadi E, Amirkhani A, Khayam Nekouei M, Haynes PA, Mardi M, Salekdeh GH. Shotgun protemic analysis of the Mexican lime tree infected with "Candidatus Phytoplasma aurantifolia". J Proteome Res. 2013;12:785-95. 
[64] Swatek KN, Graham K, Agrawal GK, Thelen JJ. The 14-3-3 isoforms chi and epsilon differentially bind client protiens from developing Arabidopsis seed. J Proteome Res. 2011;10:4076-87.

[65] Svennelid F, Olsson A, Piotrowski M, Rosenquist M, Ottman C, Larsson C, Oecking C, Sommarin M. Phosphorylation of Thr-948 at the C terminus of the plasma membrane $\mathrm{H}+$-ATPase creates a binding site for the regulatory 14-3-3 protein. Plant Cell 1999;11:2379-91.

[66] Ho SL, Huang LF, Lu CA, He SL, Wang CC, Yu SP, Chen J, Yu SM. Sugar starvation- and GA-inducible calcium-dependent protein kinase 1 feedback regulates GA biosynthesis and activates a 14-3-3 protein to confer drought tolerance in rice seedlings. Plant Mol Biol. 2013;81:347-61.

[67] Kerkeb L, Venema K, Donaire JP, Rodríguez-Rosales MP. Enhanced H+/ATP coupling ratio of $\mathrm{H}+$-ATPase and increased 14-3-3 protein content in plasma membrane of tomato cells upon osmotic shock. Physiol Plant. 2002;116:37-41.

[68] Wang G., Cai G., Kong F., Deng Y., Ma N., Meng Q. Overexpression of tomato chloroplast-targeted DnaJ protein enhances tolerance to drought stress and resistance to Pseudomonas solanacearum in transgenic tobacco. Plant Physiol Biochem. 2014;82:95-104.

[69] Soltys-Kalina D, Szajko K, Sierocka I, Sliwka J, Strzelczyk-Zyta D, WasilewiczFlis I, et al. Novel candidate genes AuxRP and Hsp90 influence the chip color of potato tubers. Mol Breeding 2015;35:224.

[70] Casati P, Walbot V. Crosslinking of ribosomal proteins to RNA in maize ribosome by UV-B and its effects on translation. Plant Physiol. 2004;136:331932.

[71] Kapp LD, Lorsch JR. The molecular mechanics of eukaryotic translation. Annu Rev Biochem. 2004;73:657-704.

[72] Muramatsu Y, Harada A, Ohwaki Y, Kasahara Y, Takagi S, Fukuhara T. Salttolerant ATPase activity in the plasma membrane of the marine angiosperm Zostera marina L. Plant Cell Physiol. 2002;43:1137-45.

[73] Debez A, Saadaoui D, Ramani B, Ouerghi Z, Koyro HW, Huchzermeyer B, et al. Leaf $\mathrm{H}$-ATPase activity and photosynthetic capacity of Cakilemaritima under increasing salinity. Environ Exp Bot. 2006;57:285-95.

[74] Epimashko S, Fischer-Schliebs E, Christian AL, Thiel G, Lüttge U. $\mathrm{Na+} / \mathrm{H}_{+}-$ transporter, $\mathrm{H}$-pumps and an aquaporin in light and heavy tonoplast membranes from organic acid and $\mathrm{NaCl}$ accumulating vacuoles of the annual facultative CAM plant and halophyte Mesembryanthemum crystallinum L. Planta 2006;224:944-51.

[75] Zaman Khan N, Lindquist E, Aronsson H. New putative chloroplast vesicle transport components and cargo proteins revealed using a bioinformatics approach: An Arabidopsis model. PLoS ONE 2013;8:e59898.

[76] Tian L, Dai LL, Yin ZJ, Fukuda M, Kumamaru T, Dong XB, Xu XP, Qu LQ. Small GTPase Sar1 is crucial for proglutelin and $\alpha$-globulin export from the endoplasmic reticulum in rice endosperm. J Exp Bot. 2013;10:2831-45.

[77] Fan L, Li R, Pan J, Ding Z, Lin J. Endocytosis and its regulation in plants. Trends Plant Sci. 2015;20:388-97.

[78] Barlowe C, Orci L, Yeung T, Hosobuchi M, Hamamoto S, Salama N, Rexach MF, Ravazzola M, Amherdt M, Schekman R. COPII: a membrane coat formed by sec proteins that drive vesicle budding from the endoplasmic reticulum. Cell 1994;77:895-907. 
Fig. 1. A representative cladode from wild and domesticated Opuntia species. Upper arrow indicates the direction of domestication, from the wildest $O$. streptacantha to the most domesticated O. ficus-indica

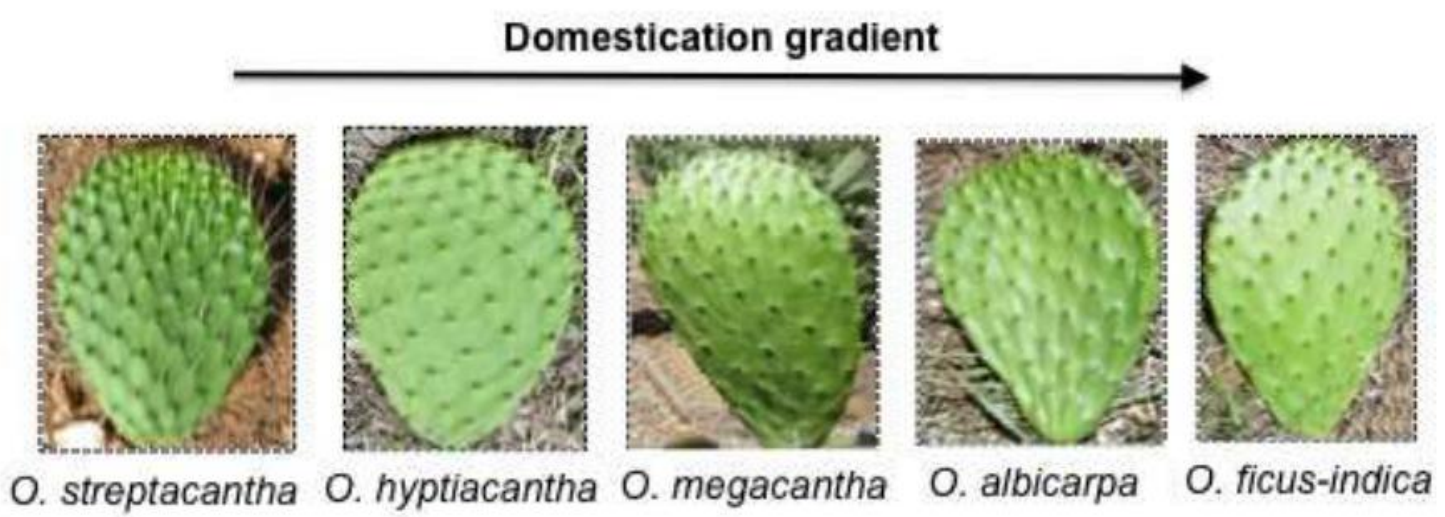


Fig. 2. Classification of the identified proteins species in Opuntia cladodes. The pay chart shows the distribution into their biological process in percentage according to Gen Ontology (http://www.geneontology.org/).

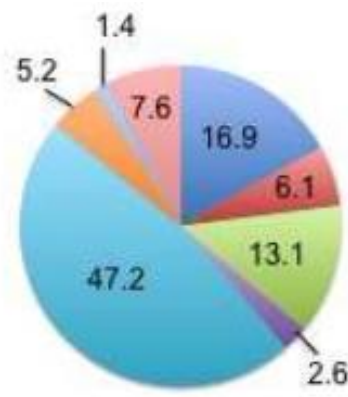

O. streptacantha

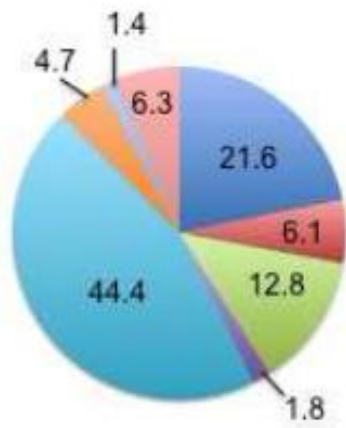

O. albicarpa

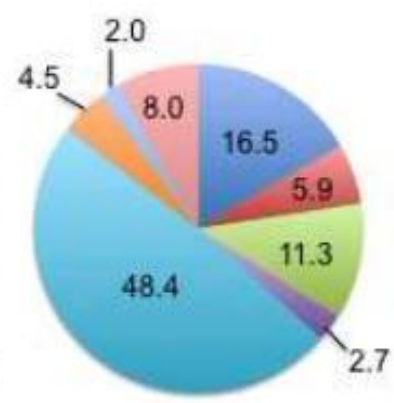

O. megacantha

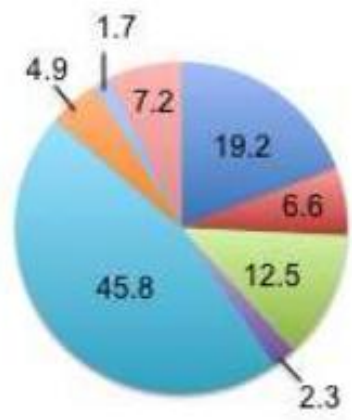

O. ficus-indica

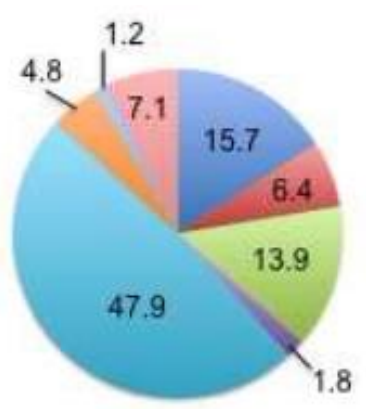

O. hyptiacantha
- Non-annotated

Eell function

Defense and response to stimulus

a Development

inetabolic process

in Regulation

ineproduction

in Transport 
Fig. 3. Distribution of different protein species belonging to the proteasome complex identified in Opuntia cladodes.

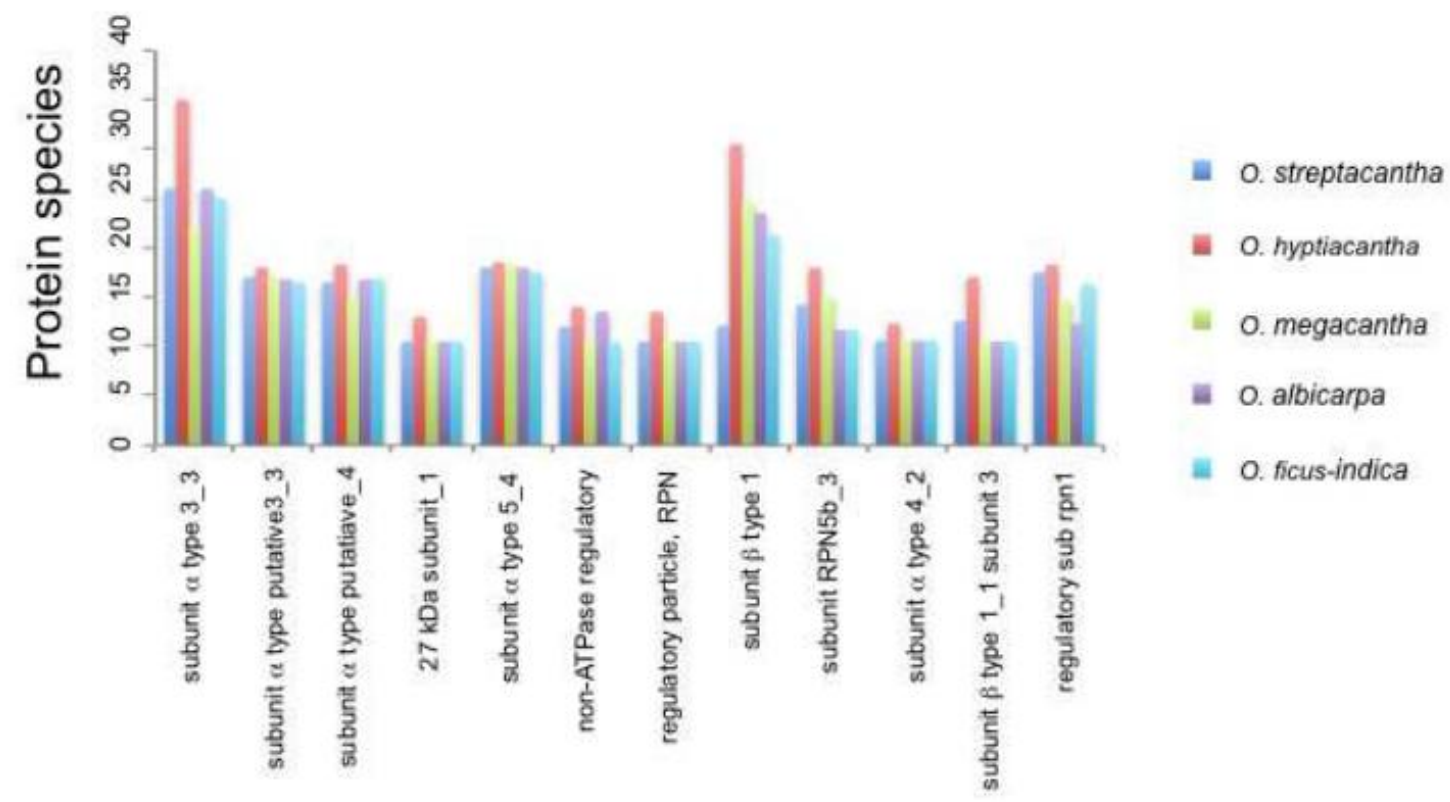


Fig. 4. Schematic representation of differentially accumulated proteins species in wild Opuntia cladodes when compared with the most domesticated O. ficusindica. Up-accumulated proteins were detected in the wildest species $O$. streptacantha and $O$. hyptiacantha (blue letters A and B, respectively). Downaccumulated proteins were detected in domesticated $O$. megacantha and $O$. albicarpa (letters $\mathrm{C}$ and $\mathrm{D}$, respectively). $\mathrm{ADH}=$ aldehyde dehydrogenase; AdoHcyase $=$ Adenosyl-homocysteinase; $\mathrm{FBP}=$ fructose bisphosphate aldolase; $\mathrm{GAPD}=$ glyceraldehyde 3-phosphate dehydrogenase; GS=glutamine synthase; $\mathrm{PEPC}=$ phosphoenolpyruvate carboxylase; $\mathrm{PK}=$ pyruvate kinase; PPDK=pyruvate phosphate dikinase; PRK=phosphoribulokinase; RuBisCO=Ribulose-1,5-bisphosphate carboxylase/oxygenase; SHMT=Sadenosyl-L-homocystein hydrolase; SOD=superoxide dismutase; SUS=sucrose synthase; Trx=thioredoxin.

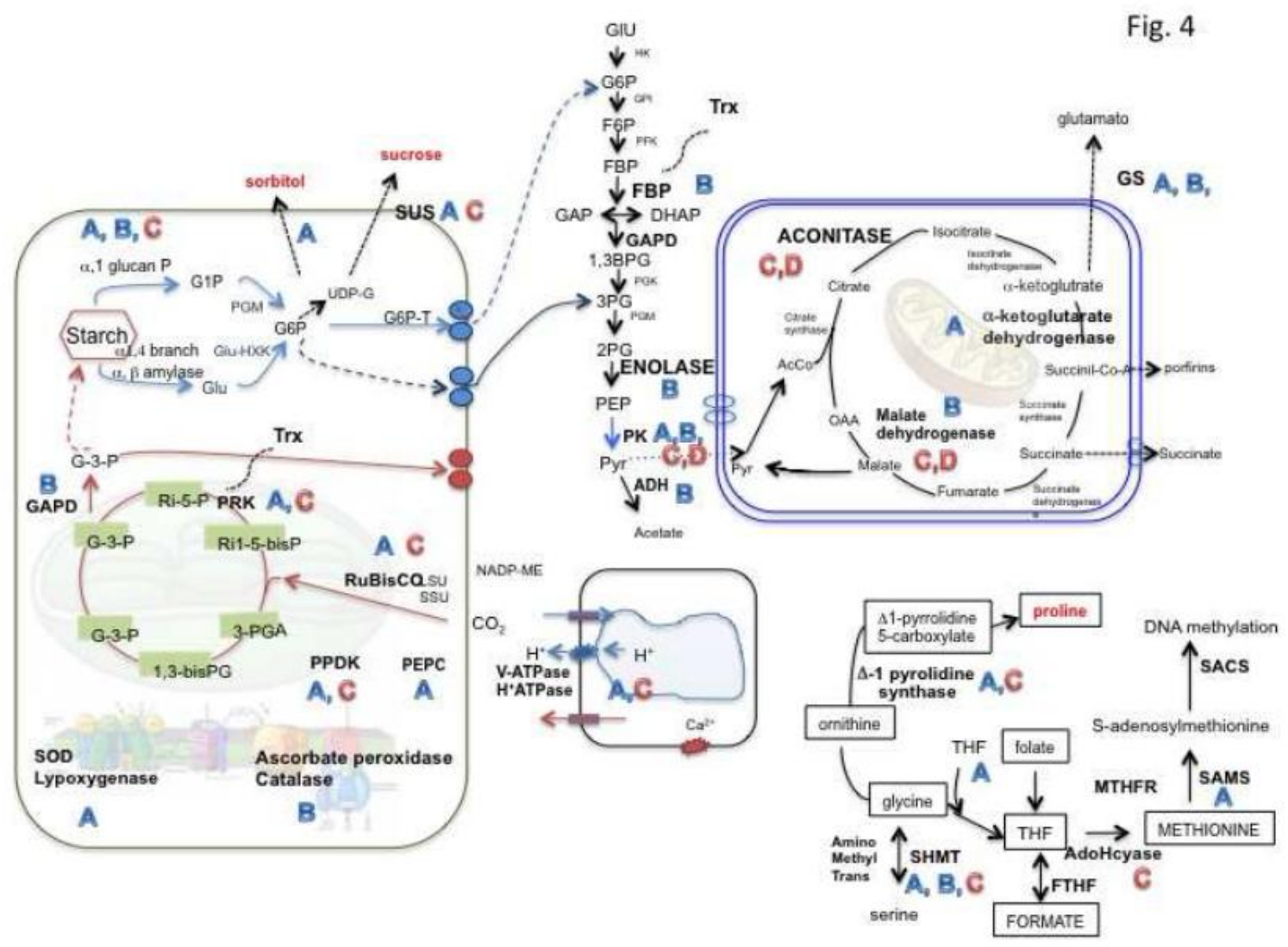


Table 1 Proximate composition and phenolic compounds of cladodes from Opuntia spp. with different domestication gradient. ${ }^{1}$

\begin{tabular}{|c|c|c|c|c|c|c|}
\hline \multirow{2}{*}{$\begin{array}{l}\text { Species/ } \\
\text { cultivar }\end{array}$} & \multicolumn{6}{|c|}{ Component } \\
\hline & Protein $^{2}$ & $\mathrm{Fat}^{2}$ & $\begin{array}{l}\text { Crude } \\
\text { fiber }^{2}\end{array}$ & $\begin{array}{l}\text { Total } \\
\text { Sugars }^{3}\end{array}$ & $\begin{array}{l}\text { Phenolic } \\
\text { acids }^{4}\end{array}$ & Flavonoids 5 \\
\hline $\begin{array}{l}\text { O. streptacantha/ } \\
\text { Tuna loca }\end{array}$ & $\begin{array}{l}11.0^{d} \\
\pm 0.13\end{array}$ & $\begin{array}{l}0.62^{c} \\
\pm 0.02\end{array}$ & $\begin{array}{l}6.52^{\mathrm{a}} \\
\pm 0.03\end{array}$ & $\begin{array}{l}61.0^{\mathrm{b}} \\
\pm 7.1\end{array}$ & $\begin{array}{l}65.1^{\mathrm{a}} \\
\pm 4.0\end{array}$ & $\begin{array}{l}19.0^{a} \\
\pm 1.0^{a}\end{array}$ \\
\hline $\begin{array}{l}\text { O. hyptiacantha/ } \\
\text { Memelo } 1\end{array}$ & $\begin{array}{l}10.5^{\mathrm{e}} \\
\pm 0.04\end{array}$ & $\begin{array}{l}0.94^{\mathrm{a}} \\
\pm 0.06^{2}\end{array}$ & $\begin{array}{l}6.58^{\mathrm{a}} \\
\pm 0.03\end{array}$ & $\begin{array}{l}37.4^{\mathrm{d}} \\
\pm 3.4\end{array}$ & $\begin{array}{c}36.1^{\mathrm{d}} \\
\pm 1.8\end{array}$ & $\begin{array}{c}18.6^{\mathrm{a}} \\
\pm 0.2\end{array}$ \\
\hline $\begin{array}{l}\text { O. megacantha/ } \\
\text { Rubí reina }\end{array}$ & $\begin{array}{l}11.3^{\mathrm{b}} \\
\pm 0.03\end{array}$ & $\begin{array}{l}-0.63^{c} \\
\pm 0.03\end{array}$ & $\begin{array}{l}5.99^{b} \\
\pm 0.22\end{array}$ & $\begin{array}{l}103.7^{\mathrm{a}} \\
\pm 4.65\end{array}$ & $\begin{array}{l}57.8^{\mathrm{b}} \\
\pm 10.4\end{array}$ & $\begin{array}{l}16.5^{b} \\
\pm 0.8\end{array}$ \\
\hline $\begin{array}{l}\text { O. albicarpa/ } \\
\text { Naranjón legítimo }\end{array}$ & $\begin{array}{l}11.2^{\mathrm{abc}} \\
\pm 0.41\end{array}$ & $\begin{array}{l}0.77^{b} \\
\pm 0.02\end{array}$ & $\begin{array}{l}6.46^{a} \\
\pm 0.02\end{array}$ & $\begin{array}{l}36.9^{\mathrm{d}} \\
\pm 7.1\end{array}$ & $\begin{array}{l}47.9^{\mathrm{c}} \\
\pm 7.1\end{array}$ & $\begin{array}{l}16.8^{\mathrm{b}} \\
\pm 1.2\end{array}$ \\
\hline $\begin{array}{l}\text { O. ficus-indica/ } \\
\text { Rojo vigor }\end{array}$ & $\begin{array}{l}11.7^{\mathrm{ab}} \\
\pm 0.43\end{array}$ & $\begin{array}{l}0.68^{\mathrm{c}} \\
\pm 0.04\end{array}$ & $\begin{array}{l}5.63^{b} \\
\pm 0.04\end{array}$ & $\begin{array}{l}56.2^{\mathrm{bc}} \\
\pm 10.9\end{array}$ & $\begin{array}{c}56.7^{\mathrm{b}} \\
\pm 4.4\end{array}$ & $\begin{array}{c}20.4^{\mathrm{a}} \\
\pm 2.4\end{array}$ \\
\hline
\end{tabular}

${ }^{1}$ values are the mean of triplicates expressed on dry weight basis \pm standard deviation. ${ }^{2}$ expressed as $\% .{ }^{3}$ expressed as $\mathrm{mg}$ dextrose $\mathrm{g}^{-1}$ of sample. ${ }^{4}$ as $\mu \mathrm{mol}$ of gallic acid (GA) $\mathrm{g}^{-1}$ sample, ${ }^{5}$ as $\mu \mathrm{mol}$ of quercetin (QE) $\mathrm{g}^{-1}$ sample. Different letter in the same column are statistically different (Tukey test $p \leq 0.05$ ). 
Table 2 Total accessions containing at minimum one validated peptide.

\begin{tabular}{|c|c|c|c|c|c|}
\hline \multirow{2}{*}{$\begin{array}{c}\text { Total numbers of } \\
\text { proteins }\end{array}$} & \multicolumn{5}{|c|}{ Opuntia } \\
\hline & $\begin{array}{l}\text { streptacantha } \\
\text { (A) }\end{array}$ & $\begin{array}{l}\text { hyptacanthia } \\
\text { (B) }\end{array}$ & $\begin{array}{l}\text { megacantha } \\
\text { (C) }\end{array}$ & $\begin{array}{l}\text { albicarpa } \\
\text { (D) }\end{array}$ & $\begin{array}{c}\text { ficus-indica } \\
\text { (E) }\end{array}$ \\
\hline Identified (UNIPROT) $^{a}$ & 13599 & 24463 & 12521 & 11428 & 14095 \\
\hline Selected & 5169 & 5415 & 3737 & 3184 & 4491 \\
\hline Validated & 1369 & 1506 & 684 & 590 & 1060 \\
\hline \multicolumn{6}{|l|}{ Protein groups } \\
\hline $\begin{array}{l}\text { ( } 60 \% \text { identity) in } \\
\text { validated proteins }\end{array}$ & 507 & & 273 & 233 & 419 \\
\hline \multicolumn{6}{|c|}{ Orthologs proteins in five species ${ }^{b}$} \\
\hline Popolus trichocarpa & $679(49.6)$ & $704(46.7)$ & 305 (44.6) & 253 (42.9) & $511(48.2)$ \\
\hline Vitis vinifera & $570(41.6)$ & $663(44)$ & $305(44.6)$ & 232 (39.3) & $412(38.9)$ \\
\hline Arabidopsis thaliana & $133(9.7)$ & $158(10.5)$ & $55(8)$ & $60(10.2)$ & $91(8.5)$ \\
\hline Zea mays & $139(10.2)$ & $163(10.8)$ & $59(8.6)$ & $62(10.5)$ & $129(12.2)$ \\
\hline Glycine max & $161(11.8)$ & $200(13.3)$ & $54(7.9)$ & $72(12.2)$ & $133(12.5)$ \\
\hline
\end{tabular}

${ }^{a}$ Viridiplante database. ${ }^{b}$ Numbers in parenthesis represents the percentage

Validation of each peptide is based on the comparison of the data between the UNIPROT database and a random database. Only the peptides with a $p$-value $<0.01$ were retained. Validated data were parsed and selected with the MFPAQ software. 
Table 3 Abundance pattern of proteins present in wild Opuntia species compared with domesticated Opuntia ficus-indica

\begin{tabular}{|c|c|c|c|c|c|c|}
\hline \multirow[b]{2}{*}{ DESCRIPTION } & \multirow[b]{2}{*}{ TAXONOMY } & \multirow{2}{*}{ ID UNIPROT } & \multicolumn{4}{|c|}{ RATIO } \\
\hline & & & $\mathbf{A} / \mathbf{E}$ & $\mathbf{B} / \mathbf{E}$ & $\mathbf{C} / \mathbf{E}$ & $\mathbf{D} / \mathbf{E}$ \\
\hline \multicolumn{7}{|l|}{ Metabolism } \\
\hline Enolase & Gossypium hirsutum & A8IMB0_GOSHI & - & 644.8 & - & - \\
\hline $\begin{array}{l}\text { Glyceraldehyde-3-phosphate } \\
\text { dehydrogenase }\end{array}$ & Solanum tuberosum & F2Q9V9_SOLTU & 5.77 & - & - & - \\
\hline $\begin{array}{l}\text { Glyceraldehyde-3-phosphate } \\
\text { dehydrogenase, predicted protein }\end{array}$ & Populus trichocarpa & B9H5U1_POPTR & 2.28 & - & 0.57 & - \\
\hline Glucose-6-phosphate isomerase, & Spinacia oleracea & G6PI_SPIOL & 3.28 & - & 0.53 & - \\
\hline Pyruvate kinase, predicted protein & Populus trichocarpa & A9P7U5_POPTR & 2.91 & 14.57 & - & - \\
\hline Pyruvate kinase, putative & Arabidopsis thaliana & Q8LEY6_ARATH & - & - & 0.35 & - \\
\hline Aldehyde dehydrogenase, putative & Ricinus communis & B9RB49_RICCO & - & 7.53 & - & - \\
\hline Phosphoglucomutase, cytoplasmic & $\begin{array}{c}\text { Mesembryanthemum } \\
\text { crystallinum }\end{array}$ & PGMC_MESCR & 2.99 & 2.86 & - & - \\
\hline Phosphoglycerate kinase & Helianthus annuus & A1Y2J9_HELAN & 2.29 & 14.88 & 0.54 & 0.49 \\
\hline $\begin{array}{l}\text { Fructose bisphosphate 1-phosphatase, } \\
\text { hypothetical protein }\end{array}$ & Vitis vinifera & A5AYR7_VITVI & 2.59 & - & - & - \\
\hline $\begin{array}{l}\text { Fructose-bisphosphate aldolase, } \\
\text { putative }\end{array}$ & Ricinus communis & B9RHD4_RICCO & 1.87 & - & 0.62 & - \\
\hline Fructose-biphosphate aldolase, & $\begin{array}{c}\text { Mesembryanthemum } \\
\text { crystallinum }\end{array}$ & O04975_MESCR & - & 128.79 & - & - \\
\hline Fructose-bisphosphate aldolase, class I & Arabidopsis thaliana & ALFC2_ARATH & - & 21.13 & - & - \\
\hline Fructose-1,6-bisphosphatase, cytosolic & Beta vulgaris & F16P2_BETVU & - & - & 0.63 & 0.64 \\
\hline Aconitase putative & Capsicum chinense & B1Q486_CAPCH & - & - & 0.60 & 0.82 \\
\hline Malate dehydrogenase & Vitis vinifera & A5BEJ8_VITVI & - & - & 0.37 & \\
\hline Malate dehydrogenase & Perilla frutescens & B0LF72_PERFR & - & - & - & 0.35 \\
\hline Malate dehydrogenase, & Oryza sativa Indica & B8B9L3_ORYSI & - & 6.31 & - & - \\
\hline $\begin{array}{l}\text { 2-oxoglutarate dehydrogenase E1 } \\
\text { component, predicted protein }\end{array}$ & Populus trichocarpa & B9HTM3_POPTR & 2.61 & - & - & - \\
\hline $\begin{array}{l}\text { Predicted protein, 4-hydroxy-4-methyl-2- } \\
\text { oxoglutarate aldolase }\end{array}$ & Populus trichocarpa & A9PFQ6_POPTR & - & 27.24 & - & - \\
\hline $\begin{array}{l}\text { Ribulose-1,5-bisphosphate } \\
\text { carboxylase/oxygenase LSU }\end{array}$ & Avonia papyracea & A2VAZ6_9CARY & 4.39 & - & - & - \\
\hline $\begin{array}{l}\text { Ribulose bisphosphate carboxylase } \\
\text { large chain }\end{array}$ & $\begin{array}{c}\text { Schlumbergera } \\
\text { truncata }\end{array}$ & RBL_SCHTR & - & - & 0.48 & - \\
\hline $\begin{array}{l}\text { Ribulose-phosphate 3-epimerase, } \\
\text { chloroplastic }\end{array}$ & Spinacia oleracea & RPE_SPIOL & 2.66 & - & - & - \\
\hline $\begin{array}{l}\text { Phosphoenolpyruvate carboxylase } \\
\text { (PEPC), hypothetical protein, }\end{array}$ & Vitis vinifera & A5AH72_VITVI & 3.43 & - & - & - \\
\hline $\begin{array}{l}\text { Pyruvate phosphate dikinase (PPDK), } \\
\text { chloroplastic }\end{array}$ & Flaveria brownii & PPDK_FLABR & 2.13 & - & 0.36 & - \\
\hline $\begin{array}{l}\text { Chloroplast glyceraldehyde-3-phosphate } \\
\text { dehydrogenase, }\end{array}$ & $\begin{array}{l}\text { Marchantia } \\
\text { polymorpha }\end{array}$ & A3QVW1_MARPO & - & 15.25 & - & - \\
\hline UDP-glucose pyrophosphorylase & Pinus taeda & A6N839_PINTA & 2.63 & - & 0.43 & - \\
\hline $\begin{array}{l}\text { UDP-glucose pyrophosphorylase, } \\
\text { predicted protein }\end{array}$ & Populus trichocarpa & B9MTE3_POPTR & - & - & 0.43 & - \\
\hline Phosphoribulokinase, predicted protein & Populus trichocarpa & B9GZT5_POPTR & 2.79 & - & & - \\
\hline Phosphoribulokinase & Zea mays & B6TYM1_MAIZE & - & - & 0.54 & - \\
\hline Sucrose synthase & $\begin{array}{l}\text { Chenopodium } \\
\text { rubrum }\end{array}$ & Q9LWB7_CHERU & 4.21 & - & - & - \\
\hline
\end{tabular}




\begin{tabular}{|c|c|c|c|c|c|c|}
\hline Sucrose synthase & $\begin{array}{l}\text { Dianthus } \\
\text { caryophyllus }\end{array}$ & D7US90_DIACA & 3.73 & - & 0.45 & - \\
\hline Alpha-1,4-glucan phosphorylase L & Cucurbita maxima & B2DG13_CUCMA & 3.49 & 20.41 & 0.47 & - \\
\hline DESCRIPTION & TAXONOMY & ID UNIPROT & $\begin{array}{l}\text { Ratio } \\
\text { A / E }\end{array}$ & $\begin{array}{c}\text { Ratio } \\
\text { B / E }\end{array}$ & $\begin{array}{c}\text { Ratio } \\
\text { C / E }\end{array}$ & $\begin{array}{c}\text { Ratio } \\
\text { D / E }\end{array}$ \\
\hline Sorbitol related enzyme & $\begin{array}{c}\text { Solanum } \\
\text { lycopersicum }\end{array}$ & Q3C2L6_SOLLC & 3.95 & - & - & - \\
\hline $\begin{array}{l}\text { UDP-glucose 6-dehydrogenase, } \\
\text { hypothetical protein }\end{array}$ & Vitis vinifera & A5AVX9_VITVI & 2.43 & - & 0.32 & - \\
\hline \multicolumn{7}{|l|}{ Photosynthesis } \\
\hline Photosystem II CP47 protein & Trithuria submersa & A4GGH0_9MAGN & 7.11 & - & - & - \\
\hline $\begin{array}{l}\text { Photosystem II CP43 chlorophyll } \\
\text { apoprotein }\end{array}$ & Smilax china & E9L381_SMICH & 6.13 & 26.48 & - & - \\
\hline $\begin{array}{l}\text { Photosystem II stability/assembly factor } \\
\text { HCF136 }\end{array}$ & Arabidopsis thaliana & P2SAF_ARATH & 3.47 & - & - & - \\
\hline $\begin{array}{l}\text { Light-harvesting complex II protein } \\
\text { Lhcb5 }\end{array}$ & Populus trichocarpa & A9PGZ3_POPTR & 2.69 & 53.16 & - & - \\
\hline PSI P700 apoprotein A2 & Cuscuta gronovii & A7M900_CUSGR & 5.39 & - & - & - \\
\hline Cytochrome b6 & Nymphaea alba & CYB6_NYMAL & 4.88 & - & - & - \\
\hline Cytochrome f & Silene cryptoneura & B0LNS1_9CARY & - & 14.51 & - & - \\
\hline $33 \mathrm{kDa}$ precursor protein of the OEC & Salicornia europaea & B5BT06_SALEU & - & 54.26 & - & - \\
\hline $\begin{array}{l}\text { NADH-ubiquinone oxidoreductase, } \\
\text { putative }\end{array}$ & Ricinus communis & B9T118_RICCO & 2.07 & - & - & - \\
\hline \multicolumn{7}{|l|}{ One-carbon metabolism } \\
\hline Serine hydroxymethyltransferase, & Ricinus communis & B9SMK7_RICCO & 3.22 & 7.52 & 0.43 & - \\
\hline Serine hydroxymethyltransferase & Zea mays & B6T7J7_MAIZE & 3.84 & - & - & - \\
\hline S-adenosyl-L-homocystein hydrolas & $\begin{array}{c}\text { Brassica oleracea } \\
\text { var. alboglabra }\end{array}$ & A7XB47_BRAOA & 2.81 & - & - & - \\
\hline S-adenosylmethionine synth & $\begin{array}{l}\text { Mesembryanthemum } \\
\text { crystallinum }\end{array}$ & METK_MESCR & 2.46 & - & - & - \\
\hline Adenosyl-homocysteinase & Picea sitchensis & B8LNU2_PICSI & - & - & 0.52 & - \\
\hline Glutamine synthetase & Avicennia marina & A5A7P7_AVIMR & 1.57 & 4.56 & - & - \\
\hline Aminomethyltransferase, mitochondrial & $\begin{array}{c}\text { Mesembryanthemum } \\
\text { crystallinum }\end{array}$ & GCST_MESCR & 4.31 & - & - & - \\
\hline Geranylgeranyl hydrogenase & \begin{tabular}{|c|}
$\begin{array}{c}\text { Mesembryanthemum } \\
\text { crystallinum }\end{array}$ \\
\end{tabular} & O81335_MESCR & 4.05 & - & - & - \\
\hline $\begin{array}{l}\text { Protochlorophyllide reductase, } \\
\text { chloroplastic }\end{array}$ & Daucus carota & POR_DAUCA & 3.22 & 5.27 & - & - \\
\hline $\begin{array}{l}\text { Unnamed protein product, cysteine- } \\
\text { synthase }\end{array}$ & Vitis vinifera & A5AFH5_VITVI & - & 8.44 & - & - \\
\hline Unknown, cellulose biosynthetic process & Picea sitchensis & A9NKS5_PICSI & - & 11.73 & - & - \\
\hline Formate--tetrahydrofolate ligase & Spinacia oleracea & FTHS_SPIOL & 3.33 & - & - & - \\
\hline Tetrapyrrole biosynthetic processes, & Glycine max & C6TIB8_SOYBN & 3.03 & - & - & - \\
\hline $\begin{array}{l}\text { Delta 1-pyrroline-5-carboxylate } \\
\text { synthetase }\end{array}$ & $\begin{array}{c}\text { Opuntia } \\
\text { streptacantha }\end{array}$ & B1NJ24_OPUST & 2.43 & - & 0.67 & - \\
\hline $\begin{array}{l}\text { Pyridoxal phosphate binding, } \\
\text { hypothetical protein }\end{array}$ & Vitis vinifera & A5ACX0_VITVI & 5.26 & - & - & - \\
\hline $\begin{array}{l}\text { Flavin adenine dinucleotide binding } \\
\text { unknown, }\end{array}$ & Picea sitchensis & A9NUH7_PICSI & 2.94 & - & - & - \\
\hline $\begin{array}{l}\text { Thiamine thiazole synthase, } \\
\text { chloroplastic }\end{array}$ & Citrus sinensis & THI4_CITSI & - & - & 0.37 & - \\
\hline \multicolumn{7}{|l|}{ ROS, oxide reduction related-pro } \\
\hline SOD & Citrus maxima & Q38PL5_CITMA & 1.90 & - & - & - \\
\hline Catalase & Picea sitchensis & A9NV82_PICSI & - & 67.45 & - & - \\
\hline Chloroplast ascorbate peroxidase & Gossypium hirsutum & C6ZDB0_GOSHI & - & 13.88 & - & - \\
\hline Cytosolic ascorbate peroxidase & Arachis hypogaea & A1Z1T1_ARAHY & - & 115.31 & - & - \\
\hline Putative glutathione peroxidase & Jatropha curcas & D6BR59_9ROSI & - & 7.31 & - & - \\
\hline
\end{tabular}




\begin{tabular}{|c|c|c|c|c|c|c|}
\hline Thioredoxin-dependent peroxidase & Nelumbo nucifera & A3FPF4_NELNU & - & 66.55 & - & - \\
\hline Predicted protein, S-S bonds & Populus trichocarpa & B9H7F9_POPTR & - & 19.65 & - & - \\
\hline Lipoxygenase, predicted & Populus trichocarpa & B9GMA4_POPTR & 2.42 & - & - & - \\
\hline DESCRIPTION & TAXONOMY & ID UNIPROT & $\begin{array}{l}\text { Ratio } \\
\text { A / E }\end{array}$ & $\begin{array}{c}\text { Ratio } \\
\text { B / E }\end{array}$ & $\begin{array}{c}\text { Ratio } \\
\text { C / E }\end{array}$ & $\begin{array}{l}\text { Ratio } \\
\text { D / E }\end{array}$ \\
\hline $\begin{array}{l}\text { (S)-2-hydroxy-acid oxidase, putative. } \\
\text { FMN binding }\end{array}$ & Ricinus communis & B9SOY9_RICCO & 2.82 & - & - & - \\
\hline \multicolumn{7}{|l|}{ Protein degradation } \\
\hline Proteasome subunit alpha, hypothetical & Vitis vinifera & A5BF27_VITVI & 2.75 & - & - & - \\
\hline Proteasome subunit alpha, hypothetical & Vitis vinifera & A5C3G9_VITVI & 2.58 & - & - & - \\
\hline $26 \mathrm{~S}$ proteasome regulatory subunit rpn 1 , & Ricinus communis & B9RVT9_RICCO & 2.96 & - & 0.50 & - \\
\hline $\begin{array}{l}26 S \text { proteasome non-ATPase regulatory } \\
\text { subunit }\end{array}$ & Medicago truncatula & B7FL82_MEDTR & 2.82 & - & - & - \\
\hline $26 \mathrm{~S}$ proteasome subunit 7, putative & Ricinus communis & B9SLJ3_RICCO & 2.54 & - & - & - \\
\hline $\begin{array}{l}\text { Presequence protease } 2, \\
\text { chloroplastic/mitochondrial-like }\end{array}$ & Vitis vinifera & F6HQC5_VITVI & 2.12 & - & - & 0.51 \\
\hline $\begin{array}{l}\text { Gamma class glutathione transferase } \\
\text { EF1Bgamma2 }\end{array}$ & Populus trichocarpa & A9PE52_POPTR & 4.28 & - & - & - \\
\hline Hypothetical protein, ubiquitin-dependent & $\begin{array}{c}\text { Arabidopsis lyrata } \\
\text { subsp. lyrata }\end{array}$ & D7MN09_ARALL & - & 9.30 & - & - \\
\hline \multicolumn{7}{|l|}{ Heat Shock Proteins } \\
\hline Chaperonin cytosolic & Glycine max & A7VJA5_SOYBN & 2.79 & - & - & - \\
\hline Heat shock protein 90 & $\begin{array}{c}\text { Vitis } \\
\text { pseudoreticulata }\end{array}$ & A8WEL7_9ROSI & 2.25 & - & - & - \\
\hline Heat shock protein, putative & Ricinus communis & B9RYP6_RICCO & - & 29.65 & - & - \\
\hline \multicolumn{7}{|l|}{ Ribosomal } \\
\hline Rab11/RabA-family small GTPase & $\begin{array}{c}\text { Physcomitrella } \\
\text { patens }\end{array}$ & A9T2Z0_PHYPA & - & 114.92 & - & - \\
\hline 40S ribosomal S3a protein, unknown & Populus trichocarpa & A9PAH0_POPTR & 3.64 & - & - & - \\
\hline $60 \mathrm{~S}$ ribosomal protein $\mathrm{L} 7$, putative & Ricinus communis & B9SDR8_RICCO & 3.40 & 85.46 & - & - \\
\hline $60 S$ ribosomal protein $L 12$, putative & Ricinus communis & B9SWB0_RICCO & - & 88.82 & - & - \\
\hline Ribosomal protein S14, putative & Wolffia arrhiza & E7EDS9_WOLAR & 3.18 & 6.43 & - & - \\
\hline $40 \mathrm{~S}$ ribosomal protein $\mathrm{S} 8$ & Zea mays & B4FE90_MAIZE & 3.18 & 10.20 & - & - \\
\hline Ribosomal protein L10 & Elaeis guineensis & B3TLL9_ELAGV & 2.78 & - & - & - \\
\hline $\begin{array}{l}\text { Eukaryotic translation elongation factor, } \\
\text { putative }\end{array}$ & Ricinus communis & B9RI35_RICCO & 2.63 & - & - & - \\
\hline $\begin{array}{l}\text { Splicing factor family protein, nucleic } \\
\text { acid binding, predicted protein, }\end{array}$ & Populus trichocarpa & B9HM33_POPTR & 2.51 & - & - & - \\
\hline Elongation factor predicted protein, & $\begin{array}{c}\text { Physcomitrella } \\
\text { patens }\end{array}$ & A9SJB4_PHYPA & 2.47 & 140.2 & 0.43 & - \\
\hline $\begin{array}{l}\text { Elongation factor } 2 \text { family, predicted } \\
\text { protein, }\end{array}$ & Populus trichocarpa & B9HH11_POPTR & - & - & 0.38 & - \\
\hline $\begin{array}{l}\text { Translation initiation factor elF-4A family, } \\
\text { predicted protein }\end{array}$ & Populus trichocarpa & B9HDC5_POPTR & - & - & 0.48 & - \\
\hline RNA-binding, unknown & Medicago truncatula & B7FMH6_MEDTR & 2.35 & - & - & - \\
\hline RNA-binding protein & Zea mays & C0P6K6_MAIZE & - & 11.52 & - & - \\
\hline $\begin{array}{l}\text { Predicted Nascent polypeptide- } \\
\text { associated complex }\end{array}$ & Populus trichocarpa & B9IDG2_POPTR & - & 11.69 & - & - \\
\hline $\begin{array}{l}\text { Unnamed protein product, Transcription } \\
\text { DNA-templated }\end{array}$ & Vitis vinifera & D7TXR6_VITVI & - & 5.70 & - & - \\
\hline \multicolumn{7}{|l|}{ Energy } \\
\hline $\begin{array}{l}\text { ATPase subunit } 100 \mathrm{kDa} \text { subunit, } \\
\text { putative vacuolar }\end{array}$ & $\begin{array}{l}\text { Mesembryanthemum } \\
\text { crystallinum }\end{array}$ & Q8GUB1_MESCR & 5.07 & - & - & - \\
\hline predicted protein, phosphorylation & Populus trichocarpa & B9HE12_POPTR & 4,6 & - & - & - \\
\hline ATP synthase & $\begin{array}{l}\text { Cucumis melo } \\
\text { subsp. melo }\end{array}$ & E5GC53_CUCME & 4.33 & 21.16 & - & - \\
\hline
\end{tabular}




\begin{tabular}{|c|c|c|c|c|c|c|}
\hline ATPase, predicted protein & $\begin{array}{l}\text { Hordeum vulgare } \\
\text { subsp. vulgare }\end{array}$ & F2CRK6_HORVD & 4.06 & - & - & - \\
\hline ATP synthase CF1 alpha subunit & Scaevola aemula & A9QC30_9ASTR & 4.03 & 35.90 & 0.46 & - \\
\hline ATP-binding, hypothetical protein & Sorghum bicolor & C5YT23_SORBI & 4.01 & - & - & - \\
\hline DESCRIPTION & TAXONOMY & ID UNIPROT & $\begin{array}{c}\text { Ratio } \\
\text { A / E }\end{array}$ & $\begin{array}{c}\text { Ratio } \\
\text { B / E }\end{array}$ & $\begin{array}{c}\text { Ratio } \\
\text { C / E }\end{array}$ & $\begin{array}{c}\text { Ratio } \\
\text { D / E }\end{array}$ \\
\hline Hypothetical protein ATP binding & $\begin{array}{l}\text { Selaginella } \\
\text { moellendorffii }\end{array}$ & D8RV35_SELML & - & 20.33 & - & - \\
\hline Unnamed protein, ATP-binding protein & Vitis vinifera & D7TI60_VITVI & - & 16.43 & - & - \\
\hline ATP-binding protein & Picea sitchensis & A9NV22_PICSI & - & 8.19 & - & - \\
\hline $\begin{array}{l}\text { ADP glucose Pyrophosphorylase small } \\
\text { subunit 1-like }\end{array}$ & Malus $x$ domestica & D6PW21_MALDO & - & 13.23 & - & - \\
\hline ATP synthase beta subunit & $\begin{array}{l}\text { Agrostistachys } \\
\text { borneensis }\end{array}$ & A0ZQ41_9ROSI & 3.32 & - & - & - \\
\hline ATP synthase subunit beta & Picea sitchensis & A9NUR7_PICSI & - & - & 0.49 & - \\
\hline $\begin{array}{l}\text { ATP synthase subunit alpha, } \\
\text { mitochondrial }\end{array}$ & Glycine max & ATPAM_SOYBN & 3.16 & - & - & - \\
\hline ATPase subunit 1 & Cycas taitungensis & E1CBG2_CYCTA & - & - & 0.52 & - \\
\hline ATP-binding, predicted protein & $\begin{array}{c}\text { Oryza sativa } \\
\text { Japonica Group }\end{array}$ & B7EPR0_ORYSJ & 3.05 & - & - & - \\
\hline Inorganic pyrophosphatase & $\begin{array}{l}\text { Chlamydomonas } \\
\text { reinhardtii }\end{array}$ & A8J0B0_CHLRE & 6.32 & 20.30 & - & - \\
\hline $\begin{array}{l}\text { Membrane trafficking and } \\
\text { transport }\end{array}$ & & & & & & \\
\hline $\begin{array}{l}\text { V-type proton ATPase catalytic subunit } \\
\text { A-like }\end{array}$ & Glycine max & D7EYG6_SOYBN & 2.51 & - & 0.42 & - \\
\hline Vacuolar $\mathrm{H}_{+}-\mathrm{ATP}$ ase subunit B & Zostera marina & A0ZSE5_ZOSMR & 2.42 & - & 0.51 & - \\
\hline Clathrin heavy chain, hypothetic & $\begin{array}{c}\text { Oryza sativa } \\
\text { Japonica }\end{array}$ & A3CE45_ORYSJ & 4.08 & - & - & - \\
\hline Coatomer subunit alpha, unnamed & Vitis vinifera & D7TQ06_VITVI & 3.83 & - & - & - \\
\hline Coatomer, hypothetical protein & Vitis vinifera & A5AHP0_VITVI & 3.09 & - & - & - \\
\hline $\begin{array}{l}\text { Chromosome region maintenance } \\
\text { protein 1/exportin, putative }\end{array}$ & Ricinus communis & B9S1Z9_RICCO & 2.36 & - & - & - \\
\hline GTP-binding protein sar1, putative & Ricinus communis & B9RNF8_RICCO & 2.13 & - & - & - \\
\hline GTP-binding protein sar1, putative & Populus trichocarpa & B9IIE7_POPTR & - & - & 0.31 & - \\
\hline \multicolumn{7}{|l|}{ Cytoeskeleton and Cell division } \\
\hline $\begin{array}{l}\text { GTP-binding, microtubules, hypothetical } \\
\text { protein }\end{array}$ & $\begin{array}{l}\text { Oryza sativa Indica } \\
\text { Group }\end{array}$ & A2YG29_ORYSI & 3.18 & - & - & - \\
\hline Actin & Glycyrrhiza uralensis & A8W4W6_9FABA & 3.16 & - & - & - \\
\hline Actin-1 & Pisum sativum & ACT1_PEA & - & - & 0.58 & - \\
\hline Alpha-tubulin & Medicago truncatula & A2Q5W0_MEDTR & 3.15 & - & - & - \\
\hline $\begin{array}{l}\text { Cell division protease ftsh-like protein } \\
\text { precursor }\end{array}$ & Populus trichocarpa & B9GQ31_POPTR & 3.01 & - & - & - \\
\hline $\begin{array}{l}\text { Cell division cycle protein } 48 \text {, predicted } \\
\text { protein }\end{array}$ & Populus trichocarpa & B9IFP5_POPTR & 2.76 & - & - & - \\
\hline
\end{tabular}

$\mathrm{A}=$ Opuntia streptacantha; $\mathrm{B}=$ Opuntia hyptiacantha; $\mathrm{C}=$ Opuntia megacantha; $\mathrm{D}=$ Opuntia albicarpa; E=Opuntia ficus-indica. Hyphen (-) indicates that no changes were observed. 


\section{Graphical abstract}
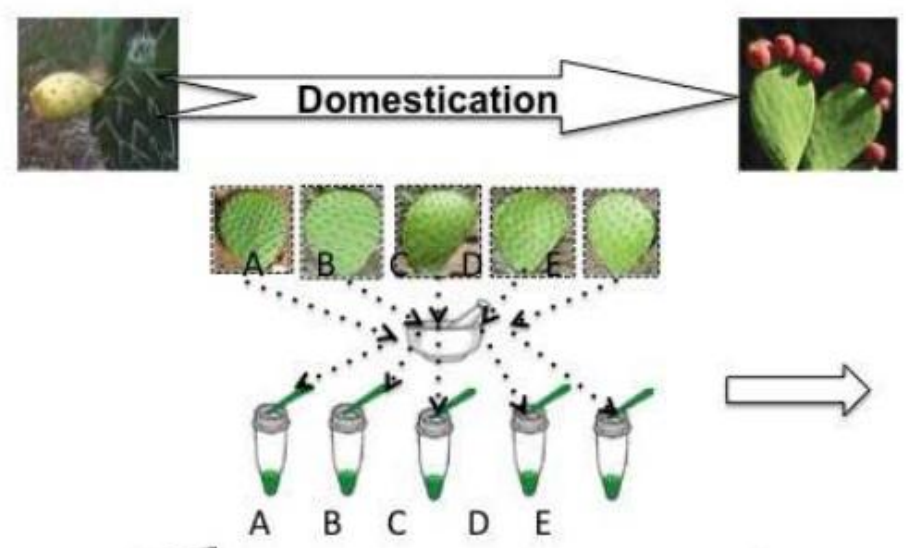

Fiber, fat, phenolic compounds
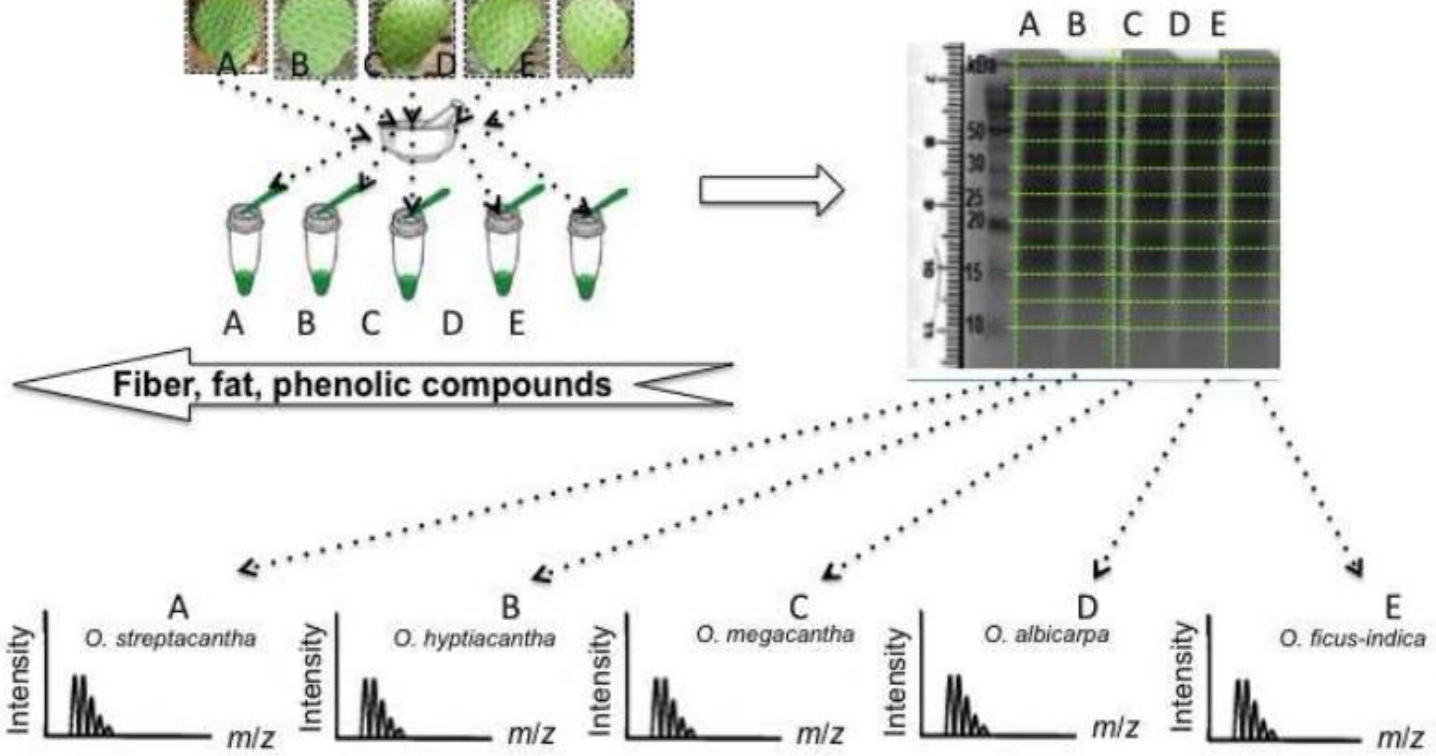

Protein species accumulation 


\section{Highlights}

- Most of the protein changes were observed in the wildest $O$. streptacantha, however $O$. megacantha presented higher levels of accumulation in glycolysis key enzymes.

- $\quad$ Most of the changes in 1C-metabolism enzymes were detected in $O$. streptacantha followed by $O$. hyptiacantha.

- Superoxide dismutase and lypoxygenase were overrepresented in 0 . streptacantha but catalase and ascorbate peroxidase were up-accumulated in O. hyptiacantha.

- Regulatory 14-3-3 proteins were detected in all Opuntia species indicating its importance for plant growing and development.

- Most of the reported key targets for increase plant resistance to abiotic stresses were well represented at protein level in wild Opuntia species. 